\title{
Different expression pattern of flowering pathway genes contribute to male or female organ development during floral transition in the monoecious weed Ambrosia artemisiifolia $L$. (Asteraceae)
}

Kinga Klára Mátyás ${ }^{1}$, Géza Hegedüs $^{2}$, János Taller ${ }^{1}$, Eszter Farkas ${ }^{1}$, Kincső Decsi $^{1}$, Barbara Kutasy $^{1}$, Nikoletta Kálmán ${ }^{3}$, Erzsébet Nagy ${ }^{1}$, Balázs Kolics ${ }^{1}$, Eszter Virág ${ }^{\text {Corresp. } 1}$

${ }^{1}$ Department of Plant Science and Biotechnology, University of Pannonia, Georgikon Faculty, Keszthely, Hungary

2 Department of Economic Methodology, University of Pannonia, Georgikon Faculty, Keszthely, Hungary

3 Departments of Biochemistry and Medical Chemistry, University of Pecs Medical School, Szentagothai Research Center, Pecs, Hungary

Corresponding Author: Eszter Virág

Email address: virag@georgikon.hu

The highly allergenic and invasive weed Ambrosia artemisiifolia L. (A. artemisiifolia) is a monoecius plant with separated male and female flowers. The genetic regulation of floral morphogenesis is a less understood field in the reproduction biology of this species. Therefore the objective of this work was to investigate the genetic control of sex determination during floral organogenesis. To this end we performed a genome-wide transcriptional profiling of vegetative and generative tissues during the plant development comparing wild-growing and in vitro cultivated plants. RNA-seq on Illumina NextSeq 500 platform with an integrative bioinformatics analysis indicated differences in 80 floral gene expressions depending on photoperiodic and endogenous initial signals. Sex specificity of genes was validated based on RT-qPCR experiments. We found 11 and 16 uniquely expressed genes in female and male transcriptomes that were responsible particularly to maintain fertility and against abiotic stress. High gene expression of homologous such as FD, FT, TFL1 and CAL, SOC1, AP1 were characteristic to male and female floral meristems during organogenesis. Homologues transcripts of LFY and FLC were not found in the investigated generative and vegetative tissues. The repression of AP1 by TFL1 homolog was demonstrated in male flowers resulting exclusive expression of AP2 and PI that controlled stamen and carpel formation in the generative phase. Alterations of male and female floral meristem differentiation were demonstrated under photoperiodic and hormonal condition changes by applying in vitro treatments. 


\section{Different expression pattern of flowering pathway}

3 genes contribute to male or female organ

4 development during floral transition in the

5 monoecious weed Ambrosia artemisiifolia L.

6 (Asteraceae)

7

8

9 Kinga Klára Mátyás ${ }^{1}$, Géza Hegedüs ${ }^{2}$, János Taller ${ }^{1}$, Eszter Farkas ${ }^{1}$, Kincső Decsi ${ }^{1}$, Barbara

Kutasy $^{1}$, Nikoletta Kálmán ${ }^{3}$, Erzsébet Nagy ${ }^{1}$, Balázs Kolics ${ }^{1}$, Eszter Virág ${ }^{1 *}$

${ }^{1}$ Department of Plant Science and Biotechnology, University of Pannonia, Georgikon Faculty, Keszthely, Hungary

${ }^{2}$ Department of Economic Methodology, University of Pannonia, Georgikon Faculty, Keszthely, Hungary

${ }^{3}$ Departments of Biochemistry and Medical Chemistry, University of Pecs Medical School, Szentagothai Research Center, Pecs, Hungary

Corresponding Author:

Eszter Virág

Festetics 7, Keszthely, Zala, 8360, Hungary

Email address: virag@georgikon.hu

\section{Abstract}

The highly allergenic and invasive weed Ambrosia artemisiifolia L. (A. artemisiifolia) is a monoecius plant with separated male and female flowers. The genetic regulation of floral morphogenesis is a less understood field in the reproduction biology of this species. Therefore the objective of this work was to investigate the genetic control of sex determination during 
29 floral organogenesis. To this end we performed a genome-wide transcriptional profiling of

30 vegetative and generative tissues during the plant development comparing wild-growing and in

31 vitro cultivated plants. RNA-seq on the Illumina NextSeq 500 platform with an integrative

32 bioinformatics analysis indicated differences in 80 floral gene expression profiles depending on

33 photoperiodic and endogenous initial signals. Sex specificity of select genes were validated

34 based on RT-qPCR experiments. We found 11 and 16 uniquely expressed genes in female and

35 male transcriptomes that were responsible particularly to maintain fertility and respond to abiotic

36 stress. Increased levels of gene expression for homologues in each tissue type of FD, FT, TFL1

37 and $\mathrm{CAL}, \mathrm{SOC} 1, \mathrm{AP} 1$ were characteristic to male and female floral meristems during

38 organogenesis. Homologue transcripts of LFY and FLC were not found in the investigated

39 generative and vegetative tissues. The repression of AP1 by the TFL1 homolog was

40 demonstrated in male flowers resulting exclusive expression of AP2 and PI that controlled

41 stamen and carpel formation in the generative phase. Alterations of male and female floral

42 meristem differentiation were demonstrated under photoperiodic and hormonal condition

43 changes by applying in vitro treatments.

44

45 Introduction

46

47

Ambrosia artemisiifolia L. (common or short ragweed, A. artemisiifolia) is a monoecious, anemophilous plant from the Asteraceae family. It produces separate male and female flower heads in the same individual, being cosexual (Lloyd D 1984). This gender system shows $5 \%$ occurrence in sexually reproducing flowering plants mainly in gymnosperm pines and plants with catkins indicating an ancestral angiosperm state (Renner SS and Ricklefs RE 1995). The numerous tiny male disc flowers are about $3 \mathrm{~mm}$ of diameter and grow in a terminal spike, subtended by joined bracts. The female flowers are one or two flowered and are inconspicuously situated below the male ones, in the leaf axils (Bassett IJ and Crompton CW 1975). Sepals are reduced and highly modified into pappus bristles. Petals form a single tubular flower, short anthers and long stigma (Figure 1). One single plant alone may produce millions of pollen grains that is increasingly important from an allergological point of view in regions of Central and Eastern Europe. The distribution of common ragweed covers the area at medium latitude characterized by continental climate started its expansion from Hungary and meaning a current problem from both agricultural and public health aspects (Makra L et al. 2004). 
60 Since in the last 20-25 years the number of ragweed pollen has dramatically increased, it would

61 be important to get a global attention and find the optimal control against the rapid spread of the

62 plant caused by extraordinary plant-adaptability, large proportion of derelict land areas, the

63 absence of specific pest insects and diseases, and not least the development of high-level

64 resistance against herbicides. Considering the invasion migratory pathways, there is high risk for

65 introduction of herbicide resistant genotypes from Eastern to Western Europe. Genomics based

66 tools therefore play an increasing role in weed research (Horvath D 2010). Understanding the

67 genetic control of sex determination during the plant life cycle may contribute to find an

68 ecologically safer strategy in the common ragweed control.

69 Flower development is a complex and accurately coordinated biological and morphological

70 process consisting spatial regulation of a considerable number of organ-specific genes during the

71 life cycle of higher plants (Taiz L et al. 2015). A large number of genes revealing floral

72 meristem and structure formation were studied extensively using the model organism,

73 Arabidopsis thaliana (A. thaliana) (Komeda Y 2004), which is a monoecious long-day plant

74 with unisexual flowers. Investigated genes discussed in this study were chosen based on the

75 genetic knowledge of Arabidopsis flowering (Chandler J 2011, Irish VF 2010). Based on

76 Arabidopsis transcriptome analysis the majority of expressed transcripts were found in the

77 reproductive part of flowers instead of the perianth, reflecting the more complex anatomy of

78 tissue and cell types within stamens and carpels and major developmental events such as ovule

79 and pollen formation (Chandler J 2011).

80 Functionally important genes (and their homologs) known to be involved in carpel and stamen

81 formation are characteristic to the floral reproductive structures in A. thaliana. Most likely

82 MADS-domain transcription factors control gene expression and hence the identity of floral

83 organs and patterning during development. The transcription factor ABORTED

84 MICROSPORES (AMS) (Lou Y et al. 2014, Xu J et al. 2010) and genes such as LESS

85 ADHERENT POLLEN3 (LAP3) (Dobritsa AA et al. 2009), LESS ADHESIVE POLLEN5 and

86 LESS ADHESIVE POLLEN6 (LAP5, LAP6) (Dobritsa AA et al. 2010) encode anther-specific

87 proteins required for pollen exine development, so called male candidate genes (Rocheta $\mathrm{M}$ et al.

88 2014). MALE SPECIFIC EXPRESSION 1 (MSE1), is specifically expressed in male flowers. It

89 is essential to early anther development (Murase K et al. 2017). Expression of

90 POLYGALACTURONASES (PG1 and PG2) and PECTIN METHYLESTERASE (PME) are 
91 characteristic in the tissues of mature pollen grains after microspore mitosis (Futamura $\mathrm{N}$ et al. 92 2000). Female candidate genes such as filamentous floral proteins AXIAL REGULATOR 93 YABBY1and YABBY4 (YAB1, YAB4) (Meister RJ et al. 2002, Siegfried KR et al. 1999, 94 Villanueva JM et al. 1999) and transcription factor AINTEGUMENTA (ANT) (Elliott RC et al. 95 1996, Klucher KM et al. 1996, Long JA and Barton MK 1998) are relevant in pollen recognition, 96 ovule formation and embryo genesis identifying pistillate tissues. STIGMA SPECIFIC1 (STIG1)

97 protein was found also as female candidate in Quercus suber described by Rocheta et al 2014 98 (Rocheta M et al. 2014). (Functional descriptions are summarized in Table 1-2).

99 The dynamic process of flowering in A. thaliana is induced from different pathways through the 100 integration of environmental (photoperiodism and vernalization) and endogenous (hormonal 101 regulation) signals. These signals trigger a complex system of interacting genes and proteins with 102 repressor and activator roles influencing one another. Corbesier et al. identified a floral inducer

103

104 105

106

107 108

109

110

111

112

113

114

115

116

117

118

119

120

121

FLOWERING LOCUS T (FT) playing an integral role between the different pathways (so called mobile 'floral integrator'), that determine the floral development (Corbesier L et al. 2007). In angiosperms the circadian clock regulates floral induction in response to seasonal changes. In most cases the day-length as the main factor of photoperiodism may affect the flowering in plants. For example Cannabis sp., Gossypium sp., Xanthium sp. respond to short day signal however A. thaliana, Avena sp., Lolium sp., Trifolium sp. respond to long day signals. In photoperiodic sensing there is a critical role of the $\mathrm{CO}$ gene.

Its gene product the CONSTANS protein is stabilized by light and initiate a complex interaction with inducers and repressors and binds to the FT promoter. Such a way may upregulate the floral inducer FTmRNA during circadian clock influenced by day-length (Putterill J et al. 1995, Samach A et al. 2000, Song YH et al. 2010, Wigge PA et al. 2005). To induce flowering during long-day lighting conditions the CO protein activate the FT-mRNA in long-day plants, however in the same conditions there is a repression process in short-day plants regulated by a lightstabilized CO ortholog Hd1, that repress the FT ortholog HEADING DATE 3 (Hd3a) (Hayama $\mathrm{R}$ et al. 2003). With the illumination of far red and blue (late afternoon lightening conditions, daylight $>700 \mathrm{~nm}$ ) translation and stability of CO is regulated by PHYTOCHROME A (PHYA) and CRYPTOCHROME (CRY) repressing the CO degradation by CONSTITUTIVE PHOTOMORPHOGENIC 1 (COP1) and SUPPRESSOR OF PHYA proteins (SPA) (Jang S et al. 2008, Laubinger S et al. 2006, Yu J-W et al. 2008). PHYTOCHROME B (PHYB) facilitates 
122 degradation of $\mathrm{CO}$ with light conditions in the morning (daylight $640-680 \mathrm{~nm}$ ) and delays

123 flowering (Song YH et al. 2013).

124 FLOWERING LOCUS C (FLC) is an epigenetic suppressor to inhibit floral induction in the 125 vernalisation pathway during the autumn period (Amasino R 2010) so called floral repressor 126 after a cold treatment. In this period the prolonged cold exposure $\left(10^{\circ} \mathrm{C}\right.$ to $\left.-1^{\circ} \mathrm{C}\right)$ is required for 127 the plant meristem to be competent to respond to floral induction conditions (Simpson GG and 128 Dean C 2002). This is important to prevent flower development during the winter months when 129 low temperatures may cause serious damage in floral tissue and most pollinators are absent. The 130 FLC mRNA high level is maintained by the FRIGIDA (FRI) allele (Gazzani S et al. 2003, 131 Michaels SD and Amasino RM 2001) downregulating the floral activators SOC1, FLOWERING 132 LOCUS D (FD) and FT. It may bind directly to the promoters of SOC1 and FD and to a region 133 in the first intron of FT, inhibiting the transcriptional activation of these genes and subsequent 134 floral transition (Helliwell CA et al. 2006, Searle I et al. 2006). VERNALIZATION 135 INSENSITIVE 3 (VIN3) plays a central role in vernalization by mediating the initial transcriptional repression of the homeotic gene FLC (Sung S and Amasino RM 2004). However,

137 due to its transient expression, it cannot maintain repression of FLC, which is then maintained by 138 Polycomb Group complexes containing VRN1 and VRN2 throughout development. Required to 139 deacetylate histones on the FLC promoter. Upon receiving the above described signals, under 140 appropriate conditions, floral meristem identity genes (FMIGs) and the homeotic floral organ 141 identity genes (FOIGs) are regulated by additional pathways. The upregulation of LEAFY (LFY) 142 and APETALA1 (AP1) (FMIGs) evocate a cascade that regulates FOIGs expression (Mandel 143 MA and Yanofsky MF 1995, Weigel D and Nilsson O 1995) toward floral whorl formation. LFY 144 interacts with a number of homeotic genes to control their expression and therefore it is directly 145 involved in the determination of floral architecture. Based on positive or negative regulation 146 effect FMIGs can be divided into two distinct classes. The first class - such as LEAFY, 147 APETALA1 and CAULIFLOWER - promotes flower meristem identity. The second class such 148 as TERMINAL FLOWER (TFL1) has the opposite effect, and maintains the identity of 149 inflorescence shoot meristems.

150 Hormonal regulation of generative development is highly dependent on the gibberellin signal and 151 may alter in different species. Gibberellin involvement in floral initiation therefore is more 152 complex. While gibberellins (GAs) promote flowering in some LD and biennial species, their 
153 effect in other species are absent or may inhibit flowering of some perennials. In the case of SD 154 plants the photoperiod flowering pathway is not decisive, therefore the GA pathway assumes a 155 major role and becomes needful. GID (GA INSENSITIVE DWARF) proteins - encoded by 156 GID1A, GID1B - are soluble GA receptors and bind with high affinity the biologically active 157 GAs, which active state is catabolized by 2-beta-hydroxylation of GA 2-oxidases (GA2OXs). 158 During flowering in response to GA, GIDs interact with specific DELLA proteins (e.g. GAI), 159 known as repressors of GA-induced growth, and target them for degradation via proteosome 160 (Griffiths J et al. 2006).

161 During the processes of floral transition the cytokinins have important role as part of the 162 hormonal regulation. It was demonstrated experimentally that the response to cytokinin treatment 163 does not require FT, but activates its paralogue TWIN SISTER OF FT (TSF), as well as FD, 164 which encodes a partner protein of TSF, and the downstream gene SOC1 (D'aloia M et al. 165 2011).

166 Floral organ identity determination is regulated by three classes of homeotic genes (FOIGs, 167 encoding the $\mathrm{A}, \mathrm{B}$ and $\mathrm{C}$ functions). The $\mathrm{ABC}$ combinatory model (Coen ES and Meyerowitz 168 EM 1991) predicts that these classes act alone or combinatorially to give rise to sepals, petals, 169 stamens and carpels. The activities of class A such as APETALA (AP1, AP2), class B such as 170 APETALA3 (AP3) and PISTILLATA (PI) and class C such as AGAMOUS (AG) are active in 171 two adjacent whorls where their individual and combined activities specify the fate of organ 172 primordia. A alone (whorl 1) specifies sepals, $\mathrm{C}$ alone (whorl 4) specifies carpels, and the 173 combined activities of $\mathrm{AB}$ (whorl 2) and $\mathrm{BC}$ (whorl 3) specify petals and stamens, respectively. 174 (The $\mathrm{A}$ and $\mathrm{C}$ activities are mutually antagonistic, such that $\mathrm{A}$ prevents the activity of $\mathrm{C}$ in the 175 outer two whorls, and $\mathrm{C}$ prevents the activity of $\mathrm{A}$ in the inner two whorls. The $\mathrm{C}$ activity is also 176 required for floral determinacy: if the $\mathrm{C}$ activity is absent, an indeterminate number of floral 177 whorls develop (Pelaz S et al. 2000). SEPALLATA (SEP1, SEP2, SEP3, SEP4) genes form an 178 integral part of models that outline the molecular basis of floral organ determination and are 179 hypothesized to act as co-factors with $\mathrm{ABC}$ floral homeotic genes in specifying different floral 180 whorls.

181 Reproduction genetics of $A$. artemisiifolia has been received poorly attention. Several study 182 focuses on the pollen and seed production, pollen allergy (Bassett IJ and Crompton CW 1975, El 183 Kelish A et al. 2014, Singer BD et al. 2005, Wayne P et al. 2002), life-cycle and reproduction 
184 strategy (Kazinczi G et al. 2008) in Ambrosia spp. However genetic information regarding 185 flowering regulation is still rare.

186 Next generation sequencing (NGS) is an advantaged technology to capture the diversity of 187 differentially expressed transcripts in male and female $A$. artemisiifolia flowers. In the present 188 work we report Illumina RNA-sequencing of two developmental stages of female flowers 189 compared with male and leaf transcriptomic data. Diversity of differentially expressed transcripts 190 between female and male inflorescence as well as leaves were analyzed comparing with 191 previously reported transcript datasets (Virág E et al. 2016). Differences between expression 192 levels of the above described flowering pathways and two gene categories such as MIGs and 193 FOIGs (ABC ortholog - MADS box genes) identified in each type of flowers are also discussed. 194 This study reports firstly about the sex-specific floral development in the common ragweed and 195 underlying genetic expression pattern. The genetic events of staminate and pistillate 196 inflorescence formation were investigated through expression analysis in wild growing and in 197 vitro cultivated plants. Focusing on the role of female flower during plant reproduction and 198 spread dynamic we present NGS data of early and late developmental phases of pistillate flower. 199 This work and related NGS project are deposited in the NCBI Bioproject under the ID 200 PRJNA335689.

201

\section{Materials \& Methods}

\section{Plant materials and cultivation conditions}

204 The RNA-seq experiments were based on common ragweed samples from four bulked 205 individuals. Seeds were collected from Cserszegtomaj, Zala county, Hungary (GPS: 46.79528, 206 17.26005) and were surface sterilized for $1 \mathrm{~min}$ in $70 \%(\mathrm{v} / \mathrm{v})$ ethanol and washed with deep water 207 for 23-30 min, followed by dipping in a 7\% solution of calcium hypochlorite with TWEEN 20 208 for $20 \mathrm{~min}$, and rinsing three times with sterile distilled water. The sterilized seeds were then 209 germinated on MS medium (Murashige and Skoog, 1962) with $0.3 \mathrm{mg} / 1$ metatopolin hormon

210 supplemented with $2 \%$ sucrose/litre and solidified with $0.8 \%$ phytoagar. The $\mathrm{pH}$ was adjusted to 2115.8 prior to autoclaving at $120^{\circ} \mathrm{C}$ for $20 \mathrm{~min}$. All the cultures were maintained at $25{ }^{\circ} \mathrm{C}$ under a 212 16/8 light/dark photoperiodic regime with a light intensity of about 2400 to 2800 lux. Node 213 segments (1.5 -2 cm long) were excised from 21- day-old plants and transferred to above 214 described MS medium. 
215 Nine developmental stages of female flowers were collected from 12 in vitro cultivated 216 individuals of common ragweed. The classification of the different phenological phases was 217 based on visual observation (Figure 1). For RNA-seq two categories of nine phenological phases $218(1 \mathrm{~F}$ and $2 \mathrm{~F}$ ) were established and combined such as early 1F (Figure $1 \mathrm{~A}-\mathrm{C}$ ) and late 2F (Figure 2191 G-I) developmental stages. Male flower buds were collected from genotypes used in F, M, L 220 transcriptoms (Virág E. et al. 2016). For gene expression comparision we used $1 \mathrm{M}$ and $2 \mathrm{M}$ 221 libraries as indicated in the Figure 1 (J-L, 1M; P-Q, 2M). In order to equal distribution, we 222 determined the weight of the samples from each developmental stages (Supplementary Table 1). 223 Along RT-qPCR analysis we used four additionally wild growing genotypes (collected in 224 Keszthely, Zala county, Hungary, GPS: 46.7654716, 17.2479554)

\section{RNA-seq library construction and sequencing}

227 Samples were frozen in liquid nitrogen immediately after collection. RNA extraction and on228 column DNase digestion were performed from each categories using TaKaRa Plant RNA Extraction Kit (Takara Bio Inc; Japan) following the manufacturer's instruction. RNA integrity and quantity were assessed on an Agilent 2100 Bioanalyzer (Agilent Technologies; USA). $2.0 \mu \mathrm{g}$ of total RNA from $1 \mathrm{~F}, 1 \mathrm{M}$ and $2 \mathrm{~F}, 2 \mathrm{M}$ samples were used as starting material for cDNA synthesis and library construction. Enrichment of mRNA, cDNA synthesis and library preparation for Illumina NextSeq paired-end sequencing were carried out using TruSeq ${ }^{\mathrm{TM}} \mathrm{RNA}$ sample preparation kit (Low-Throughput protocol) using an oligo(dT) $)_{18}$ as described by Virág E et al. 2016. The RNA-Seq was performed using Illumina NextSeq5000 system. Raw sequence data in FASTQ format were deposited in the NCBI SRA database under the accession SRR5965731 (1F) and SRR5965732 (2F). We used 1M and 2M for gene expression comparison in the case of investigated genes. $1 \mathrm{M}$ and $2 \mathrm{M}$ transcriptom datasets and their analysis will be published elsewhere.

240 Sequence reads of male inflorescence (M), leaves (L) and female (F) inflorescence containing all 241 nine developmental stages were used from earlier reported and deposited data in National Centre 242 for Biotechnology Information's (NCBI) Sequence Read Archive (SRA) under the accession 243 SRP08007 (Virág E et al. 2016). 
245 Construction of $A$. artemisiifolia transcript datasets, identification of differentially

246 expressed (DE) sequences and filtering pistillate specific transcripts

247 During preprocessing raw reads quality were examined using the FastQC quality control

248 software (Andrews S 2010). Based on FastQC report, sequences found to be represented more

249 than $0.1 \%$ of the total and low-quality bases (corresponding to a $0.1 \%$ sequencing error rate)

250 were removed and trimmed using a self-developed application 'GenoUtils' written in Visual

251 Studio integrated development environment in C\#. Conversion of .fastq to fasta files was also

252 performed using this in house application.

253 A sample-specific multiple assembly of cleaned reads from five libraries (M, L, F, 1F and 2F)

254 were performed. De novo assembly of each sample type were performed by using Trinity (Haas

255 BJ et al. 2013). For reference guided alignments Bowtie2 short read aligner (Langmead B et al.

256 2009) was applied. The assembly strategy was performed in a way with taking into account the

257 refinement of pistillate tissue specific sequences in both developmental classes as the final

258 outcomes. Assembly strategy is summarized in the flow chart (Figure 2). In detaile. First, a

259 combined read set was assembled from the three sample libraries (M, F and L) to generate a

260 'reference' de novo transcriptome assembly that was deposited in the NCBI TSA database under

261 the accession GEZL00000000 and reported in our prior study (Virág et al. 2016). During this

262 processes, reads with certain length of overlap were combined to form contigs ( $\mathrm{kmer}$ size, $\mathrm{K}$, =

263 25). This combined dataset was used as reference shotgun assembly in the further alignments. In

264 order to perform sample-specific expression analysis, we screened the differentially expressed

265 sequences by aligning the original sample reads to the reference followed by abundance

266 estimation using RSEM (Li B and Dewey CN 2011). The resulting differentially expressed

267 transcripts were further clastered according to their expression patterns by applying Microsoft

268 SQL Server Management Studio. Protein coding regions were extracted from the reference

269 assembly using TransDecoder and further characterized according to likely functions based on

270 sequence homology or domain content using BLAST+ (Altschul SF et al. 1990). In this way

271 coding sequences (CDS) as unique transcripts of each five samples were screened and compared.

272 Separately, de novo assemblies of $1 \mathrm{~F}$ and $2 \mathrm{~F}$ libraries were performed using Trinity and

273 deposited in the NCBI TSA database under the accession GFWB00000000 (1F) and

274 GFWS00000000 (2F). Using these reference contig sets $1 \mathrm{~F}$ and $2 \mathrm{~F}$ unique transcripts were 
275 realigned applying BLASTn with E value less than $10^{-5}$. The resulting narrowed and specified 276 sequences were annotated using NCBI nr protein database.

277

\section{Selection of genes for floral transcriptome characterization}

279 Genes representing different floral regulatory pathways - stimulated by environmental and 280 endogenous signals - were selected for characterize genetic events during male and female floral

281

282

283

284

285

286

287

288

289

290

291

292

293

294

295

296

297

298

299

300

301

302

303

304

305 development. Architecture formation were analized by determining $\mathrm{ABC}(\mathrm{E})$ genes expression pattern at generative growth (differences in FOIGs). Genes that enable and promote floral meristem initiation during vegetative growth (FMIGs) such as photoperiodic, vernalisation, gibberellin pathway and flower development genes (Figure 3, Figure 4) were also investigated in both wild growing and in vitro samples. Normalized expression of selected genes were performed digitally and expression values were compared.

\section{Digital gene expression analysis}

The obtained reads from each library were mapped to the selected gene CDSs by using Bowtie2. The mapped reads were used to estimate the transcriptome level by the reads per kilobase per million mapped reads (RPKM) method (Mortazavi A et al. 2008):

$$
R P K M=\frac{\operatorname{CDS} \text { read count } * 10^{9}}{\operatorname{CDS} \text { length } * \text { total mapped read count }}
$$

In this equation CDS represent the coding sequence of the investigated gene. Read count means the mapped reads from the total. CDS length is the nucleotid sequence length of coding region of the investigated gene and total mapped reads are the total raw reads of given cleaned library. For automatic calculation of RPKM values of genes a self developed pipeline as modul of GenoUtils were applied.

\section{Gene expression analysis with RT-qPCR amplification}

Reverse transcription was performed starting from $1 \mu \mathrm{g}$ total RNA using Maxima H Minus First Strand cDNA Synthesis Kit with dsDNase (Thermo Scientific) according to the manufacturer's protocol, using an oligo(dT) 18 and random hexamer primers (Thermo Scientific), final volume was $20 \mu \mathrm{l}$. cDNA $(1 \mu \mathrm{l})$ was used for real-time PCR amplification on a Bio-Rad CFX96 System. qPCR analysis (and efficiency) was performed with $1 \mu 1$ of cDNA on a Bio-Rad CFX96 System using Xceed qPCR SG Mix (Institute of Applied Biotechnologies). The relative gene expression 
306 was calculated with $\Delta \Delta \mathrm{Ct}$ method using Bio-Rad CFX Manager ${ }^{\mathrm{TM}}$ Software v3.1. Primer

307 efficiency was analyzed with CFX Manager ${ }^{\text {TM }}$ Software v3.1 (Bio-Rad). PCR was performed as

308 follows: an initial activation of the polymerase enzyme at $95{ }^{\circ} \mathrm{C}$ for $2 \mathrm{~min}$ was followed by 46

309 cycles at $95{ }^{\circ} \mathrm{C} 5 \mathrm{sec}, 59^{\circ} \mathrm{C}$ for $30 \mathrm{sec}$, ended with a $5 \mathrm{sec}$ melt analisys ranging between $65-95$

$310{ }^{\circ} \mathrm{C}$ with 0.5 increments. Primers (Supplementary Table 2) were designed with Primer3

311 (Koressaar T and Remm M 2007, Untergrasser A et al. 2012) based on in silico sequence

312 prediction of CDS.

313 Gene expression analysis was established based on three technical and biological replicates, and

314 normalized with the reference gene glyceraldehyde-3-phosphate dehydrogenase (GAPDH)

315 (Hodgins KA et al. 2013). In a pilot experiment GAPDH was selected as reference gene. In this

316 investigation based on the literature CDS of fifteen housekeeping genes were determined.

317 Subsequently the relative expression levels were determined in three sample types (L, M, F)

318 were six reference genes showed the same level, respectively. Among the equally expressed

319 genes three reference genes $(G A P D H, T U A, T U B)$ were selected for RPKM value calculation

320 (Supplementary Table 3) and PCR experiments. GAPDH was the most characteristic along these

321 investigations. Based on RPKM values GAPDH expression referd on equivalent level order of

322 magnitude level in each liberies ranging from 2480-4914.

323

324 Annotation of DE transcripts

325 Whereas A. artemisiifolia floral transcriptome was a newly targeted transcriptome the annotation

326 procedure was performed as described by Haas et al. 2013 (Haas et al. 2013). Potential coding

327 regions within reconstructed transcripts that were insufficiently represented by detectable

328 homologies to known proteins were predicted based on metrics tied to sequence composition by

329 applying TransDecoder include with Trinity. Running this application on the Trinity-

330 reconstructed transcripts the candidate protein-coding regions could be identified based on

331 nucleotide composition, open reading frame (ORF) length, and (optional) Pfam domain content.

332 To predict their functions the latest non-redundant protein database 10/03/2016

333 (ftp://ftp.ncbi.nlm.nih.gov/blast/db/FASTA/nr.gz) were used.

334 For further annotation of unigenes using various bioinformatics approaches, the unigenes were

335 firstly searched against the Nr database and the Swiss-Prot protein database using local BLASTx

336 (Gish W and States DJ 1993) with E value cutoff of $10^{-5}$. With Nr annotation, Blast2GO (Götz S

Peer] reviewing PDF | (2019:01:34305:3:0:NEW 27 Jun 2019) 
337 et al. 2008) was used to get $\mathrm{GO}$ annotation according to molecular function, biological process

338 and cellular component ontologies http://www.geneontology.org.

339

\section{Results}

341 In this study we present an RNA-seq approach to get closer to the mechanism of floral

342 development in A. artemisiifolia using Illumina sequencing. In order to investigate the

343 expression distribution of genes taking part in floral morphogenesis, we categorized transcript

344 datasets of female and male flowers including whole investigated phenophases (F, M), leaves (L)

345 and female and male flowers in early and late developmental stages (1F, 2F, 1M, 2M). For

346 normalized F, M and L transcript libraries, we used the SRA dataset reported in our prior study

347 (Virág E et al. 2016) provided the first step in the common ragweed floral genomics. For 1F, 2F,

$3481 \mathrm{M}, 2 \mathrm{M}$ libraries early and late categories of phenophases were collected and sequenced de novo

349 from in vitro and wild growing plants.

350

351

\section{RNA sequencing and assembly of $A$. artemisiifolia floral libraries}

352 The M, F and L libraries were obtained through HiSeq2000 platform. Library construction and

353 assembly was described detailed in our prior study, Virág E et al., 2016. In brief, after cleaning

354 we obtained 18,472,374 (M); 15,290,200 (F) and 17,435,976 (L) from total raw reads of

355

356

357

358

359

360

361

362

363

364

365

366

367 $24,110,256 ; 23,264,636$ and 24,330,693 ( $2 * 100 \mathrm{bp})$. Assembly of combined read sets resulted in 229,116 transcripts and 162,494 trinity genes (unigenes) and used as a reference (Supplementary Table 4).

A total of $39,664,366(1 \mathrm{~F})$ and $37,127,852(2 \mathrm{~F}) 2 * 80 \mathrm{bp}$ reads were generated by the Illumina NextSeq500 system. High quality ( $>$ Q20) bases were more than $91 \%$ in (paired-end) reads of both sample. Percentage of unresolved bases (Ns) and overrepresented sequences was observed to be minimal $0.197 \%$ and $0.0004 \%$ in average. In total of $92 \%$ were high quality sequences from raw data: numerically $36,491,216(1 \mathrm{~F})$ and $34,157,623(2 \mathrm{~F})$. These high quality, processed paired-end reads were used to assemble into contigs and transcripts. Their de novo assembly resulted in 109,452 (1F) and 97,239 (2F) contigs. In comparision the reference guided assembly led to $40 \%$ more contigs $147,457(1 \mathrm{~F})$ and 141,58 (2F), respectively. However, N50 length showed a minor 5-11\% dispersion between the ranges $626.9-697.5$ in both methods. Sequencing statistics are summarized in Supplementary Table 4. 
369 Selection of $\boldsymbol{A}$. artemisiifolia unique and differentially expressed genes

370 In order to identify exclusively expressed transcripts in the sex-specific floral tissues we used

371 Bowtie2 alignments of F, M, L, $1 \mathrm{~F}$ and $2 \mathrm{~F}$ libraries for the Ambrosia reference transcriptome

372 GEZL00000000. In order to prove the $1 \mathrm{~F}$ and $2 \mathrm{~F}$ exclusive transcripts in female sample (F),

373 contigs were realigned using BLASTn algorithm to the $1 \mathrm{~F}$ and $2 \mathrm{~F}$ de novo Trinity transcripts

374 (GFWB00000000, GFWS00000000). Filtering method is summarized in Figure 2. The transcript

375 datasets were extracted from Trinotate heat map and postprocessed using Microsoft SQL Server

376 Management Studio (Supplemental files Dataset S1). The queries for unique organ specific

377 sequences resulted in 5659 (M), 1691 (F) and 4267 (L). The number of exclusive and shared

378 transcripts in wild growing male and female flowers and leaf are visualized in Venn diagram. For

379 visualisation we used FunRich (V3) software (Pathan M et al. 2015) (Figure 5). The number of

380 annotable unique transcripts were 11300 in M, F and L libraries. Among which the most

381 important organ specific genes are summarized in Table 3-4 and their sequences are in a

382 supplemental file Dataset S2. The presented genes were within the upper limit ( $>80 \%)$ of the

383 total expression level value.

384

385 Annotation and functional classification of $\boldsymbol{A}$. artemisiifolia unigenes

386 Functional annotation of the transcriptome sequences and analysis of the annotation of three-

387 specific RNA pools (M, F, L) were performed using BLASTx search (Gish W and States DJ

388 1993) and Blast2GO (Conesa A et al. 2005). This process resulted in $81.56 \%$ translated contigs

389 in total. Based on GO annotation the cell part, organic cyclic compound binding and organic

390 substance metabolic process were the most abundant GO slims in the categories of cellular

391 component, molecular function and biological process, respectively (Supplementary Figure 1).

392 The high physiological activity of Ambrosia reproductive tissues was suspected from the high

393 representation of primary metabolic process and cellular metabolic process groups within the

394 biological process category.

395 Representation of the significant sub-ontologies of cellular component, molecular function, and

396 biological process are summarized in the Supplementary Figure 1. GO enrichment analysis were

397 performed with the investigated floral genes wich resaults are summarized in Supplementary 
398 Figure 2 -4. Statistics and background information can be found in supplement Dataset S4 and $399 \quad$ S5.

400

401

402

403

404

405

406

407

408

409

410

411

412

413

414

415

416

417

418

419

420

421

422

423

424

425

426

427

428

\section{Validation of the $A$. artemisiifolia floral transcriptome}

The identification of differences between the male and female floral transcriptomes was based on in silico analysis. We performed a local blast alignment by using the determined 80 CDS fasta sequences (MK098047- MK088126) against male (M) and female (F) transcriptoms. No qualitative differences were found among the sequences of commonly expressed genes in two floral organs. The blast output files are in the Supplemental files Dataset S3. The observed expression differences were validated investigating the transcript expression levels of homolog genes responsible for pollen and embryo formation in model organism A thaliana. The reliability of male transcriptome was characterized by overexpression of the homologs of $A M S$, LAP3, LAP5, LAP6, MSE1, PME, PG1, PG2. The female transcriptome validity was justified by overexpression of $Y A B 1, Y A B 4$ and $A N T$ transcription factors. Additionally, we introduced SUPERMAN (SUP, MK098096, GO:0003676), Transcription repressor MYB5 (MYB5, MK098099, GO:0003677), Transcription repressor MYB61 (MYB61, MK098101, GO:0003677) and Protein BRANCHED2 (TCP12, MK098098, GO:0003700) as female candidate genes based on our filtering by Microsoft SQL Server Management Studio. These regulators are involved in plant and floral tissue development, but their role during sex determination is still unclear. Expression differences and function of organ specific genes are summarized in Table 1-2.

\section{RT-qPCR validation of tissue specific genes}

For the RT-qPCR validation we selected the genes showing the largest differences (Table 1-2) and most interesting from functional aspects. TCP12, SUP and LAP6 were selected to justify their exclusive expression in female and male flowers. STIGl were chosen according to its opposite expression in male flowers. Additionally we selected also PI (MK098083, GO:0000977) as ABC transcript exclusively present in staminate tissues.

\section{Gene expressions during floral meristem initiation (vegetative growth)}

27 Functional and structural analysis of $A$. thaliana gene homologs were investigated to elucidate floral regulation in the common ragweed. Expression pattern of photoperiodic, vernalization, 
429 gibberellin and flower development pathways comparing with floral architecture formation are 430 summarized in Figure 3 and Figure 4.

431

\section{Gene expressions during floral architecture formation (generative growth)}

433 The $\mathrm{ABC}(\mathrm{E})$ genes responsible for the formation of flower organs were determined on the basis 434 of various compositae species (Gerbera sp, Helianthus sp, Tagetes sp, Chrysanthemum sp) found 435 in public databases (NCBI, UNIProt). The coding sequences and their expression patterns of the 436 following thirteen gene homologs were determined: AP1(MK098082), AP2 (MK098081), AP3 1 437 (MK098086), AP3 2 (MK098085), AP3 3 (MK098084), PI, AG (MK098087), SEP1 438 (MK098094), SEP2 1 (MK098092), SEP2 2 (MK098091), SEP3 1 (MK098090), SEP3 2 439 (MK098089) and SEP4 (MK098088) (Figure 3, Figure 4). All of investigated floral organ genes 440 except AP2 (GO:0003677) have the same GO ID: GO:0000977.

441

442 Transcription factors differentially expressed in F, $\mathrm{M}$ and $\mathrm{L}$ libraries

443 Based on analysis of the different TF groups that are sex-specific and differentially expressed in 444 each library the following factors were identified in our samples according to Rocheta et al. 2014 445 (Rocheta $\mathrm{M}$ et al. 2014). Gene expression values of all investigated libraries and functional 446 descriptions are summarized in Supplementary Table 5 and Supplementary Table 6.

447

\section{Expression of female flower specific genes}

449 In order to identify exclusively expressed genes in female flowers, the combined assembly of 450 five (M, L, F, 1F and 2F) non-normalized libraries were analysed. In the analysis, 1691 unique 451 transcripts were found in the wild growing F library, representing the nine developmental stages. 452 Transcripts longer than $700 \mathrm{bp}$ were further investigated. After this filtering, we found 60 453 transcripts showing evaluable ORF, among which nine genes were well annotable using NCBI nr 454 and Swiss-Prot databases. Based on this, the following protein coding and transcription factors 455 were identified: Protein kinase 1A (PBL9, MK098095, GO:0004674), SUP, Alpha carbonic 456 anhydrase-7 (ACA7, MK098097,GO:0004089), Laccase-2 (LAC2, MK098102, GO:0005507),

457 TCP12, MYB5, MIB61, Zinc finger protein WIP2 (MK098100, GO:0003677), and Protein 458 Brassinosteroid enhanced expression 1 (BEE1, MK098103, GO:0006355) (see Table 3). In 459 order to find genes that might correspond to early and late flower development, exact CDSs of 
460 these genes were determined in silico and validated with sanger sequencing from in vitro plant 461 materials. RPKM values were calculated in F, L, M, 1F, 2F, 1M and 2M libraries using validated 462 CDSs.

463

464 Expression of male flower specific genes

465 The uniquely expressed transcript number in male tissues were 4549 (Figure 5) of which 466 sequences longer than $700 \mathrm{bp}$ were filtered out. In this way total coding sequences of 41 genes 467 were identified based on NCBI nt Blast and NCBI ORF finder databases. The 12 most 468 characteristic male specific genes, RPKM values and functional properties are summarized in 469 Table 4.

470

\section{Discussion}

472 Genetic control of floral morphogenesis is a well investigated field in the model plant $A$.

473 thaliana. Using Arabidopsis hermaphrodite flowers and their mutants some genetic models were 474 established for structural development of floral organs in which a series of sequential steps were 475 defined, for review see Krizek and Fletcher 2005 (Krizek BA and Fletcher JC 2005). As the 476 initial destination the floral meristem are regulated through the activation of FMIGs by flowering 477 pathways. Subsequently, the floral meristem is patterned into the whorls of organ primordia 478 through the activity of FOIGs. Than the FOIGs activate downstream effectors that specify the 479 various tissues and cell types that constitute the different floral-organ types. Each of these steps 480 are under strict genetic network control of positive and negative factors and regulatory elements 481 interacting at various levels to regulate floral morphogenesis. Using NGS RNAseq there is a 482 great possibility to investigate expression profile of these pathways in non-model organisms like 483 A. artemisiifolia, where the male and female floral organs grow as separate entities in the same 484 individual plant. Rocheta et al. report on a comparative study revealed a transcript dataset to be 485 involved in flower and plant development in the monoecious tree Quercus suber with similar 486 disjunct gender system where the male flowers form catkins and female inflorescence grow on 487 young leaf axils separately. This floral transcriptome analysis revealed a group of genes 488 expressed exclusively in each type of flower genders that may have a functional role in the 489 sexually different floral organ development and sex specification (Rocheta M et al. 2014). 
491 Validation of the $A$. artemisiifolia floral transcriptome

492 As expected, the investigated genes showed differential expression ratios with a meaningful 493 results according that male tissues were characterised with an overexpression of genes $(A M S$, 494 LAP3, LAP5, LAP6, STIG1, PG1, PG2, PME, MSE1) taking part in pollen structural 495 development, fatty acid and exine constituent biosynthesis during the anther and pollen 496 differentiation. In contrast, expression of these genes was completely absent in the pistillate 497 tissues in which ovule polarity, initiation, structural development and embryogenesis influencing 498 genetic elements ( $Y A B$ class transcription factors) showed about $67 \%$ higher presence than in 499 staminate samples. The non-exclusive occurrence of these sequences in pistillate flowers may be 500 explained by the contribution to setting up the polarity in stamen maybe through their action in 501 supporting the development of the floral meristem or/and regulating margin growth (Eshed Y et 502 al. 2004) that was observed also in all lateral organs (Chen Q et al. 1999, Siegfried KR et al. 503 1999). Additionally, the validation method was confirmed through the very low incidence of 504 candidate sequences in leaf transcriptomes.

505

506

507 To evaluate the results, genes were grouped according to their specificity. According to this, the 508 female transcriptome was validated based on TCP12 and SUP expressional pattern. Female 509 specificity of SUP and TCP12 was confirmed (Figure 6 B). The expression of TCP12 was three 510 times higher than of the SUP in female flowers confirming the in silico RPKM results. Male 511 transcriptome was validated according the expression pattern of LAP6, STIG1 and PI. The non 512 exclusive expression of PI was observed indicating the ABC function and B class activity in both 513 flower types. Since in female flower the petal differentiation is vestigial and this whorl is united 514 into a single tubular flower, therefore PI homolog transcript are less present than in male flowers 515 where petals are united into short anthers with long stigma and stamen structures represents a 516 large amount.In silico expession of STIG1 homologe in male flowers (Table 1) were confirmed 517 by RT-qPCR, indicating the modified pistil origin in the pistillodium structure. Howerver this 518 transcript showed a minimal expression also in female flowers (Figure 6 A). This fenomena 519 reveals the common origin of these flower types which were separated during evolutuion.

\section{Gene expressions during floral meristem initiation (vegetative growth)}


522 Plant development and architecture is regulated by meristems that initiate lateral organs on their

523 flanks. Gene regulatory networks that control the transition of a vegetative shoot apical meristem 524 into an inflorescence meristem (FMIGs), together with those necessary to specify floral meristem 525 identity (FOIGs) have been explored in A. thaliana and are highly complex and redundant. We 526 have evaluated and report the most prominent cases in this study. Since the morfogenesis of the 527 in vitro cultivated female inflorescence of common ragweed is more intensive than in wild528 growing plants, therefore genetic regulation of the pistillate inflorescence can be more 529 effectively investigated in these samples. The investigated pathways and related genes showed 530 the following correllations. No interaction was found between $L F Y$, FRIGIDA (FRI) and FLC 531 transcription factors that determine the initiating steps during vegetative growth. Homologous 532 transcript of this genes were not found in any of the investigated libraries, and were not 533 expressed in the examined samples. This indicates, that the blossom phase has exceeded the 534 initial signals in the bio-rythm of collected samples. The combined expression of $L F Y$ and FLC 535 leads to the so-called "late-flowering phenotype" (Michaels SD and Amasino RM 2001) absent 536 in the $1 \mathrm{~F}$ and $2 \mathrm{~F}$ individuals confirming the complete lack of expression of these genes, that may 537 be traced back to the altered hormonal conditions (cytokinin-supplemented culture medium) 538 during in vitro cultivation.

539 Overexpression of photoperiodic pathway related transcripts of $P H Y B$ (MK098056, 540 GO:0000155) in 1F, 2F, $1 \mathrm{M}$ and 2M libraries and COP1(MK098059, GO:0009785), CO 541 (MK098060, GO:0005634) and FT (MK098073, GO:0008429) in the L library were found.

542 Significantly higher expression of PHYB than PHYA (MK098057, GO:000155) were observed in 543 all samples independently of the cultivation conditions indicating the red (morning) illumination 544 affects more intensively the flowering processes in A. artemisiifolia. These results confirm the 545 findings of Deen et al at genetic level, according which $A$. artemisiifolia belongs to the short day 546 plants (Deen W et al. 2001). The transcription of FT is activated by CO in leaf, and the FT

547 protein moves to the shoot apex to induce flowering, therefore we found these transcripts 548 overexpressed only in leaf tissues in wild-growing samples. Since A. artemisiifolia is a short day 549 plant, higher expression of COPl in leaf may be explained by the function to repress $\mathrm{CO}$ 550 degradation (Song YH et al. 2010). Interestingly, FT-mRNA was only detected in early stage 551 inflorescences $(1 \mathrm{~F})$ suggesting that the initial flowering signal loses its regulatory function 
552 during female flower development, and transcription factors responsible for floral organ

553 development come to the fore as control elements.

554 The vernalization pathway gene homolog VRN1(MK098069, GO:0003677), showed high values

555 in all developmental stages $(1 \mathrm{~F}, 2 \mathrm{~F}, 1 \mathrm{M}, 2 \mathrm{M})$, which function is to inhibit the flowering

556 repressor $F L C$, thus maintain generative morphogenesis of the flowering meristem. Expression

557 of VRN1 was increased during female flower maturation (Sung S and Amasino RM 2004). We

558 found SOC1 (MK098072, GO:0000957) homolog in 1F and 2F libraries. SOC1 can integrate

559 flowering signals from different pathways and interact with FT-mRNA to develop inflorescence.

560 The SOC1-FT interaction, based on gene expression values, showed intensive regulation in the

561 early stages of the common ragweed (1F).

562 SOCl associating with AGL24 (MK098093, GO:0000977) mediates effect of gibberellins on

563 flowering under short-day conditions, and regulates the expression of $L F Y$, which links floral

564 induction and floral development (Liu C et al. 2008). The lack of SOCl, LFY (RPKM=0) and

565 overexpression of $F T$ (RPKM=1487) in wild-growing samples indicated that flowering transition

566 was regulated more intensively by the photoperiodic pathway in this samples. In contrast,

567 hormonal pathway related genes (SOC1, GIDIA (MK098047, GO:0016787), GAI (MK098050,

568 GO:0003712), Ga2ox8 (MK098051, GO:0016491), CAL (MK098071, GO:0000977), AGL24)

569 were more expressed in in vitro plants. Therefore we concluded, that both cultivation condition

570 reached the $A P 1$ expression that is the "first pass" of floral architecture formation, however the

571 vegetative pathway was altered under in vitro conditions. This phenomena has led to altered

572 morphology and genesis of floral genders. The female inflorescences grow faster and in greater

573 abundance in the case of in vitro individuals than in the wild-growing plants (see Figure 7). Male

574 inflorescences, however were barely appeared in vitro. Under wild-growing conditions male

575 flowers dominate because of the intense lightening mediated signals.

576 The effective integration of hormonal signaling in plant vegetative growth is essential in which

577 gibberellins and cytokinins act antagonistically in leaf formation and meristem maintenance

578 (Gan Y et al. 2007). Cytokinins may act antagonistically with GA preventing $L F Y$ induction (Li

$579 \mathrm{~J}$ et al. 2017) that was observed in $1 \mathrm{~F}$ and $2 \mathrm{~F}$ samples in our flowering system. However, their

580 integrative role in flower formation is still contested. We demonstrated the importance of

581 cytokinins as part of hormonal regulation during Ambrosia floral transition (overexpression of

$582 T S F$ in L library), however no sex-specificity was observed (low RPKM values in $1 \mathrm{~F}, 2 \mathrm{~F}, 1 \mathrm{M}$, 
583 2M libraries). We demonstrated also that cytokinin signaling may act positively on GA-pathway

584 genes during flowering therefore gibberellin pathway genes (GIDIA and GID2 (MK098049,

585 GO:0005515) ) were found overexpressed in female inflorescences.

586

587 Gene expressions during floral architecture formation (generative growth)

588 The $A P 2, A P 32$ and $P I$ genes were not or very low expressed in the female samples, therefore

589 we considered them as male specific genes of common ragweed. PI with $A G$ determine the

590 stamen and $A P 2$ with $A P 3$ determine the petal formation that are male flower elements in the

591 common ragweed (Figure $8 \mathrm{~A}$ ). The expression of the APl gene showed a significantly higher

592 value in female flowers than in the male inflorescence, suggesting that the initiation of petals and

593 stamens is stronger in the pistillate flowers. This overexpression may be traced back to the

594 hormonal pathway domination and through SOC1 during vegetative phase in female flowers

595 (Kaufmann K et al. 2010). In the early stage of development of female inflorescences (1F) a high

596 expression rate were found for SEP1, SEP2, SEP3 and SEP4. Supposedly these genes are

597 responsible for the development of petal and carpel primordias. Hovewer, SEP3 2 and SEP2 2

598 showed high expression in the late phase (2F) that may be involved in the pistill prolongation

599 (Figure 8 B).

600

601 Transcription factors differentially expressed in $\mathbf{F}, \mathbf{M}$ and $\mathrm{L}$ libraries

602 Transcription factors (TFs) play important roles in plant development and flower morphogenesis

603 responding to the environment. These factors interact specifically with sequences located in the

604 promoter regions of the genes they regulate. Transcription factors are classified in families

605 according to the structure of their DNA-binding domain.

606 Based on RPKM values, homologs of CONSTANS-LIKE zink-finger TF family was found to be

607 characteristic in both female and male samples (COL4, MK098124, GO:0005634, COL5,

608 MK098125, GO:0005634). Upregulation of COL4 was found in 1F and 2F libraries indicating a

609 stronger interaction of female tissues with the circadian clock and light signals than in male

610 flowers. COL4 null mutants flowered early under short or long days. In contrast, OsCOL4

611 activation-tagging mutants $(O s C O L 4-D)$ flowered late in either environment (Lee YS et al.

612 2010). Of these the late flower showed higher RPKM value in the correspondence of CO

613 transcript level. Down regulation of COL9 (MK098126, GO:0005634) was observed in all wild-

Peer] reviewing PDF | (2019:01:34305:3:0:NEW 27 Jun 2019) 
614 growing samples. Since overexpression of $C O L 9$ also delayed flowering by reducing expression 615 of CO and FT (Cheng XF and Wang ZY 2005), our results confirm the natural circadian rhythm 616 of wild growing samples. Over-expression of $C O L 5$ can induce flowering in short-day grown 617 Arabidopsis (Hassidim M et al. 2009). We observed the higher COL5 expression in female 618 flowers, mainly in the case of in vitro plants where pistillate flowering showed intensive growth 619 under short light conditions.

620 The next most characteristic transcript was an ILR3 (MK098117, GO:0046983) homologue of 621 IAA-LEUCINE RESISTANT 3 protein representing the helix-loop-helix protein family. ILR3 is 622 required to maintain $\mathrm{Fe}$ homeostasis in correlation with a large amount of $\mathrm{Fe}^{3+}$ observed in the 623 sepals in A. thailana (Zhang J et al. 2015). Since this transcript was found to be expressed 624 roughly equally in all investigated samples ( $1 \mathrm{~F}, 2 \mathrm{~F}, 1 \mathrm{M}, 2 \mathrm{M}, \mathrm{M}$ and $\mathrm{L})$, approximately, we 625 assumed that to keep at appropriate level the iron homeostasis is essential to all flower types in 626 fact to maintain hormonal and redox balance for fertility (Sudre D et al. 2013).

627 Among the hormone related factors the auxin responsive AUX/IAA protein family genes such as 628 IAA27 (MK098121, GO:0005634) and IAA9 (MK098120, GO:0005634) were found to be 629 characteristic in both reproductive tissues. These transcriptional factors are repressors of early 630 auxin response genes at low auxin concentrations (Liscum E and Reed J 2002). RT-qPCR and in 631 situ hybridisation have shown that tissue-specific gradient of IAA9 expression which was 632 established during flower development, and the release of which, upon pollination and 633 fertilisation, triggers the initiation of fruit development (Wang $\mathrm{H}$ et al. 2009). Theese results 634 explain the higher expression rate in female tissues in both early and late phenophases in 635 Ambrosia. The auxin efflux carrier homolog, PIN-FORMED 1 (PIN1,MK098122, GO:0009734) 636 was also found to be upregulated in early female flowers $(1 \mathrm{~F})$ indicating the female tissue 637 determination might be under strong control of auxin. These results correspond to the study of 638 Ceccato et al. where PIN1 expression and cellular localization in the ovule were essential for 639 correct auxin efflux in early stages of female gametophyte development (Ceccato L et al. 2011). 640 In the ethylene response pathway the protein ETHYLENE INSENSITIVE3 (EIN3, MK098123, 641 GO:0003677) regulates ethylene responsive genes as a positive regulator and results in flowering 642 delay via repression of the floral meristem-identity genes $L F Y$ and SOCl (Achard P et al. 2007). 643 In our flowering system it was upregulated in $\mathrm{M}, 1 \mathrm{M}, 2 \mathrm{M}$ libraries resulting no expression of $644 S O C 1$ and $L F Y$ in male tissues (see Figure 3 and Figure 4). No $L F Y$ homolog was identified in 
645 any of the floral libraries in corellation of higher expression of this transcription factor. Wild 646 growing Ambrosia individuals grow male flowers intensively in late summer, which is a delayed 647 state compared to the female blossom. However, SOCl transcript was found only in the in vitro 648 samples referring to the altered (earlier) floral regulation we assumed that this fenomena is based 649 on changes in hormonal pathways.

650 NAC-domain containing transcription factors are essential for normal plant morphogenesis 651 which representatives are the CUP-SHAPED COTYLEDON proteins encoded by CUC1 652 (MK098118, GO:0003677) and CUC2 (MK098119, GO:0003677) genes less expressed in our 653 flower samples. Mutations in Arabidopsis $C U C l$ and $C U C 2$ caused fusion of cotyledons, sepals, 654 and stamens suggesting that these factors are responsible for mechanisms that separates organ 655 developing at adjacent positions (Aida M et al. 1997). No expression of CUCl was detected in 656 wild growing pistillate tissues and its expression was lowest among the investigated transcription 657 factors in staminate samples. In in vitro samples $C U C 2$ was expressed only in early phenotypes 658 (1F) in female flowers with a minimal expression rate. Since these factors are involved mainly in 659 early development of cotyledonary primordia (Aida M et al. 1997), the phenomena of 660 downregulation of these genes may be explained by the flowering separation that has overtaken 661 this critical state in our samples.

662 The homeodomain like MYB transcription factors are involved in the control of the cell cycle of 663 plants. The majority of them are miRNA regulated and are involved in numerous cell 664 biochemical pathways like hormonal regulation. The gibberellin pathway related MYB33 665 (MK098116, GO:0003677) homolog was expressed only in male flower in wild growing 666 Ambrosia samples in a correspondence with Rocheta et al, and Millar et al, in which studies the 667 GAMYB-Like MYB33 was proved to facilitate anther development redundantly (Rocheta $\mathrm{M}$ et al. 668 2014, Millar AA and Gubler F 2005). In in vitro originated 1F and 2F libraries homologue 669 transcripts of MYB33 were also found indicating repeatedly altered hormonal regulation of this 670 system.

671

672 Expression of female flower specific genes

673 As expected, all of these investigated genes are not expressed in M, L, 1M and 2M libraries 674 (RPKM=0) except of $B E E 1$ in leaf samples with a very low value. In early female flower 675 development the serine/threonine protein kinase PBL9 (MK098095, GO:0004674) showed an 
676 exceptionally high value. SUP, TCP12 and MYB5 were expressed two times greater than in 677 matured flowers before the ovule formation. Two catalytic protein genes $L A C 2$ and $A C A 7$ were 678 also found as unique genes in late $2 \mathrm{~F}$ samples with low expression suggesting a not characteristic 679 role, but taking part in necessary metabolic processes during floral maturation $680 P B L 9$ (alternatively APK1) is very weakly expressed in flower tissues. It was described as $A$. 681 thaliana serine/threonine protein kinase that phosphorilates tyrosine, serine and threonine 682 (APK1) during signal transduction (Hirayama $\mathrm{T}$ and Oka A 1992). The $A P K$ family is negatively 683 regulated by the floral homeotic protein AG (AGAMOUS) (Ito T et al. 1997) involved in the 684 control of organ identity, which expression was equal in early and late female libraries, 685 respectively. Unique expression of $P B L 9$ in female flowers indicated that the development of 686 staminate and pistillate tissues are regulated by different kinases at protein level during signal 687 transduction mechanisms. Similarly, a receptor-like protein kinase was also reported as female 688 specific gene in the monoecious Quercus suber (Rocheta M et al. 2014). Additionally, different 689 expression of these gene showed altered protein phosphorilation during female flower formation, 690 accurately it is more significant at the beginning of the pistillate flower development.

691 Despite of SUP is not a sex determination gene (not located on the sex - Y - chromosome) it 692 was considered as female specific gene. Their function in female flower differentiation pathway 693 was proved in dioceious plant $S$. latifolia. During the development of the female flower in $S$. 694 latifolia, the expression of SUP is firstly detectable in whorls 2 and 3 when the normal 695 expression pattern of the B-class flowering genes was already established and persisted in the 696 stamen primordia until the ovule had matured (Bowman JL et al. 1992, Kazama Y et al. 2009). It 697 is probably controlled by sex determination genes on the $\mathrm{Y}$ chromosome in dioecious plants.

698 The role of MYB transcription factor superfamily in plant reproductive development is 699 unequivocal. MYB proteins include a conserved domain, the MYB DNA-binding domain 700 regulating a variety of plant-specific processes and they may play roles in different plant species 701 (Ambawat $\mathrm{S}$ et al. 2013). For example R2R3 MYB and MYB88 regulates female flower 702 reproduction in A. thailana (Makkena S et al. 2012), MYB35 (MSE) regulates male specific 703 expression in Asparagus officinalis (Murase K et al. 2017). MYB1 and MYB16 regulates petal 704 development in Petunia Hybrida and A. thailana (Baumann K et al. 2007, Noda K-i et al. 1994). 705 Overexpression of MYB61 was demonstrated in several aspects of plant growth and 706 development, such as xylem formation and xylem cell differentiation, and lateral root formation 
707 (Arsovski AA et al. 2009, Liang Y-K et al. 2005, Matías-Hernández L et al. 2017, Romano JM 708 et al. 2012). Importance in seed coat formation, trichome morphogenesis and mucilage secretion 709 of MYB5 and MYB61 was also described by several studies (Arsovski AA et al. 2009, Gonzalez 710 A et al. 2009, Li SF et al. 2009, Liu C et al. 2014) indicating overexpression in seed coat and 711 siliques. In our investigations $M Y B 5$ and MYB61 showed unique expression in female flowers, 712 however MYB5 (MK098099) MYB61 (MK098101) was found to be more characteristic in early 713 and late phenophases respectively.

$714 T C P 12$ belongs to the plant-specific transcription factor family TCPs. The founding members of 715 this family have been characterized to be involved in growth, cell proliferation, and organ 716 identity in plants (Yang X et al. 2012). TCP1-like genes are involved in floral development with 717 different regulatory and evolutionary mechanisms underlying the diverse forms of floral 718 symmetry, such as dorsal/ventral dosage effect (Busch A et al. 2011). We found that the female 719 specific TCP12 was stronger expressed in earlier phenophases suggesting a TCP12-related 720 zygomorphic regulation at the beginning of floral morphogenesis in this species.

721 The transcription factor $B E E 1$ is a positive regulator of brassinosteroid signaling (BR) regulating 722 plant development and physiology. The BR signal is transduced by a receptor kinase-mediated 723 signal transduction pathway which ultimately results in altered expression of numerous genes. 724 During flowering brassinosteroids stimulate floral transition through positively regulating the 725 circadian clock pathway genes and inhibiting FLC repressor (Domagalska MA et al. 2007, Zhu 726 J-Y et al. 2013). Deficiency of this phytohormones lead to the delay of flowering and because of 727 the disruption of the pollen tube, BR deficient plants are practically male-sterile (Clouse SD 728 1996). Characteristic overexpression of the BR enchancer BEEl uniquely in late-female flowers 729 suggest on one hand an altered regulation of BR signal transduction than in male flower 730 development, on the other hand it confirms an enhanced BR mediated floral transition related to 731 circadian clock in A. artemisiifolia.

732 Transcription factor WIP2 is a zink finger protein and was found to be responsible for 733 transmitting tract formation in the gynoecium, which is important for pollen tube growth 734 (Crawford BC and Yanofsky MF 2008). WIP2 plays role in replum development and regulation 735 of $A G L 8 / F U L$ (MK098076, GO:0000957), which is required for normal pattern of cell division, 736 expansion and differentiation during morphogenesis of the silique (Marsch-Martínez $\mathrm{N}$ et al. 
737 2014). Expression of this gene was equal in early and late developmental flowers indicating an

738 intensive cell division in the gynoecial tissues during fruit development.

$739 L A C 2$ is a multicopper-containing glycoprotein belonging to the laccase family. The exact

740 function of $L A C$ genes is not yet cleared. Laccase genes were highly expressed in lignifying

741 tissues and are known to be associated with lignin synthesis (Gavnholt B and Larsen K 2002,

742 Sato Y et al. 2001). In Arabidopsis array experiments the majority of investigated laccase

743 members were found primarily in root tissues and in flower and stem samples secondly. In a

744 mutant screening experiment $L A C 8$ and $L A C 2$ deficient mutants lead to early flowering and

745 reduced root elongation phenotypes. $L A C 2$ expression was also detected in flower tissues in the

746 Arabidopsis array (TAIR database) (Gavnholt B and Larsen K 2002). In our Ambrosia flowering

747 system $L A C 2$ was found expressed uniquely in late, however, $2 \mathrm{~F}$ flowers, were represented with

748 a reduced value of order compared to the other female specific genes.

749 The role of $A C A 7$ in flowering pathways is not yet reported. It belongs to the $\mathrm{Zn}$ metalloenzymes

750 carbonic anhydrases (CAs) that catalyse the reaction of reversible hydration of CO2 with

751 exceptionally high efficiency. CAs have been involved in a broad range of biochemical processes

752 that involve carboxylation or decarboxylation reactions including photosynthesis and respiration.

753 CAs also participate in $\mathrm{pH}$ regulation, inorganic carbon transport, ion transport, water and

754 electrolyte balance (Henry RP 1996, Smith KS and Ferry JG 2000, Tashian RE 1989). However,

755 an interesting correlation revealed, that $A C A 7$ location was mapped on the same chromosome

756 region as EARLY FLOWERING 3 (ELF3) including the earliness per se locus Eps-Am1 in

757 diploid wheat (Triticum monococcum). This locus affects the duration of early developmental

758 phases and it is responsible for the optimal photoperiod sensing and vernalization during

759 flowering time (Gavnholt B and Larsen K 2002). Due to $A C A 7$ location it may be considered that

760 carbon-based catalytic processes are strongly related to $A C A 7$ in female flower development in

761 A. artemisiifolia. These results suggest that female flower differentiation may differ mainly in

762 regulatory elements of the flowering pathway genes such as altered signal transduction and

763 transcription factor activity.

764

765 Expression of male flower specific genes

766 Of the annotable genes, the mostly expressed sequences showed homology with the followings: 
767 The homolog of desiccation-related protein, PCC13-62 (MK098104, GO:no terms) showed the

768 highest RPKM value, 1126.37, which is activated during the drought stress in the pollen, seeds, 769 and vegetative organs in succulent plants (Giarola V et al. 2018). It was expressed exclusively in 770 the stylopodium of the hermaphrodite flower in Mucona sempervivens, where the nectary is

771 located (Zha H-G et al. 2013). Since the male flower pistillodium is a modified pistil with a 772 function to help dispensing the pollen from staminate flowers in A. artemisiifolia (Payne WW 773 1963), the anatomical presence of this transcript may be explained. Functionally however, this 774 protein may serve to protect the cytoplasmic contents in the pollen, since the pollen grain is an 775 extremely desiccated structure at maturity. Desiccation-related proteins were also reported in the 776 A. thailana columbia ecotype pollen (Sheoran IS et al. 2006).

777 The second most significantly expressed sequence was the CYP450 86B1 (MK098105,

778 GO:0004497) homolog. This gene was found to be expressed in many parts of the flower,

779 including epidermis, anther and pistil. In young inflorescences this gene effects the suberin and 780 cutin biosynthesis playing an important role in defensive mechanisms during biotic and abiotic 781 stresses and supports the maintenance of reproduction (Compagnon V et al. 2009, Duan $\mathrm{H}$ and 782 Schuler MA 2005).

783 The third most significantly expressed gene homolog was found from the lipolytic enzyme 784 family, GDSL2 (MK098106, GO:0016021), which was expressed during petal differentiation and 785 is responsible for lipid catabolic processes (Ji R et al. 2017). Ji et al. identified a GDSL lipase 786 gene in Brassica rapa playing an important role in the anther and pollen development.

787 Arabidopsis GDSL lipase 2 plays role in pathogen defense via negative regulation of auxin 788 signaling and a positive correlation between late flowering and resistance to $F$. oxysporum in $A$. 789 thaliana natural ecotypes was observed related to GDSL lipases (Lyons R et al. 2015).

790 The above described male characteristic genes with outstanding high RPKM values refer to the 791 most intensive physiological processes that are related to pollen exposure and stability and biotic 792 and abiotic defense during anther formation.

793 Because all of the most male characteristic genes are related to flowering, secondary metabolism, 794 plant cell structure, biotic and abiotic stresses, these may be considered to be essential to male 795 specificity in the common ragweed. Gene homologs discussed below were found to be important 796 for male flower physiology based on RPKM values. TET8 (MK098111, GO:0016021), which 797 encodes a transmembrane protein tetraspanin 8 , member of tetraspanin family. TET8 play 
798 important role in plant development, reproduction and stress responses (Reimann $\mathrm{R}$ et al. 2017).

799 Expression of tetraspanins including tetraspanin 8 were described during the pollen development 800 and in mature pollen in A. thaliana (Boavida LC et al. 2013, Honys D and Twell D 2004, Pina C 801 et al. 2005). pMADS2 was found expressed in flowers in the second whorl, however in 802 vegetative organs were not found in Petunia (van der Krol AR et al. 1993). In Ambrosia, this 803 gene was found to be homologous to PI that is predominantly expressed in petals and stamens, 804 and less in carpels and sepals. The 3-oxoacyl-[acyl-carrier-protein] synthase coding $O A S$ 805 (MK098107, GO:0006633) is responsible for the condensation reaction of fatty acid synthesis 806 and confers resistance to low temperatures by maintaining chloroplast membrane integrity 807 (Dayan FE and Duke SO 2014). This protein is also involved in the regulation of fatty acid ratio 808 during seed metabolism. It is required for embryo development, especially at the transition from 809 globular to heart stage (Hakozaki H et al. 2008). Another gene family responsible for membrane 810 structure, the syntaxins (SYN) showed also unique expression in male tissues. These proteins 811 play role in fusion of transport vesicles to target membranes. Inactivation of genes from two 812 syntaxin families has led to lethality of the male gametophyte (Sanderfoot AA et al. 2001). NIP 4 8131 and NIP 42 are pollen specific aquaporins playing role in pollen germination and pollination 814 in A. thailana. These genes are essential to the growth of pollen tubes and were considered to be 815 exclusive components of the reproductive apparatus of angiosperms with partially redundant 816 roles in pollen development and pollination (Di Giorgio JP et al. 2016).

817 MYB proteins are a superfamily of transcription factors that play regulatory roles of gene 818 expression controlling direct organ development and defense responses in plants. We found 819 uniquely expressed MYB transcription factors related to flower development in male tissues. 820 MYB80 (MK098109, GO:0003677) showed the highest expression in male tissues playing an 821 essential role during anther development and production of tapetum and microspores (Higginson 822 T et al. 2003) (Phan HA et al. 2011).MYB26 (MK098115, GO:0003677) regulates lignified 823 secondary cell wall thickening of the anther endotechium, which is necessary for anther 824 dehiscence. It may play role in specifying early endothecial cell development by regulating a 825 number of genes linked to secondary thickening (Mitsuda N et al. 2006, Yang C et al. 2007). 826 MYB35 (MK098110, GO:0003677) is required for anther development and early tapetal function 827 during microspore maturation. It regulates callose dissolution and is required for microspores 828 release from the tetrads (Zhu J et al. 2011). The MYB44 (MK098112, GO:0003677) represses the 
829 expression of protein phosphatases $2 \mathrm{C}$ in response to abscisic acid (ABA). It confers resistance

830 to abiotic stresses dependent of ABA. The overexpression of AtMYB44 enhanced stomatal

831 closure to confer abiotic stress tolerance in transgenic Arabidopsis (Jung C et al. 2008).

\section{2}

\section{Conclusions}

834 Genetic program of formation of separated male and female flower development in monoecious plants is a less understood mechanism in flowering biology. Available genomic data of the majority of these species are insufficient or inexistent to date. It makes more difficult, that the reproduction biology of $A$. artemisiifolia is less studied and the majority of information has been revealed exclusively in the pollen formation as part of male flowering biology. Today, large DNA or RNA data sets of non-model organism may be attainable using NGS technology, therefore we sequenced and compared transcriptome libraries of wild growing male, female, leaf and in vitro female flowers representing early and late developmental phases. Comparative studies revealed a subset of transcripts that were differentially expressed in the different libraries

843 known in flower or plant development in A. thaliana. However, genes showing differential 844 expression previously were not characterized in A. artemisiifolia during flowering.

845 Genome-wide transcriptional profiling in five libraries revealed a surprising number of 846 transcripts that were differentially expressed playing role - non exclusively - in plant or flower 847 development, but also in signal transduction, redox and abiotic stress mechanisms. Induction of 848 floral meristem initiation is proceeded by a complex regulation network just in the vegetative 849 phase which regulatory elements are the so called flowering pathway genes. Based on expression pattern of these pathways we demonstrated that the common ragweed belongs to the short-day plants and flowering induction depends on $P H Y B$-related light signals. Because of the small

852

853

854 855 856 857 858 859 amount of collectable pistillate flowers, plants were also in vitro cultivated on meta-topolin supplemented media. In this way, influence of hormonal and photoperiodic pathways were modelled on the flowering pathway genes. Based on gene expression differences of flowering pathways in male and female samples and the shifts to intensive female morphogenesis under in vitro cultivation conditions, we concluded that before the generative transition, the determination of floral gender takes place just in vegetative phase during the vegetative pathway dominancy that defines the subsequent floral organ morphogenesis. Transition to AP1 and FOIGs induction is leaded by hormonal and photoperiodic pathways depending on which dominancy the female or 
860 male flower initiation come into being. Thus, flower identity is decided just in vegetative growth.

861 Investigation of male flower showed that photoperiodic pathway induce the generative transition

862 through FT/FD complex, however gibberellin-related SOC1 expression was not observed

863 indicating it has no role in male gender formation. On the other hand, expression of FT/FD was

864 lacking in in vitro female samples that was favourable to SVP (MK098077, GO:0000977) or

$865 A G L 24$. Transcripts of $L F Y$ homolog were not found in any of the libraries, therefore it appears

866 likely that floral organ development is induced through $L M I$ - CAL regulation in female.

867 However, FUL and directly (AP1) - AP2 regulation in male flowers in only induced when the 868 AP1 repression by TFL1 was also experienced. Expression analysis of transcription factors 869 confirmed the greatest importance in regulation of the circadian clock taking part in progress or 870 delay of flowering. The followings are in order the hormonal-redox balance to maintain fertility 871 and the structural and morphological regulations during A. artemisiifolia reproduction.

872

\section{Acknowledgements}

874 We express our thanks to our retired colleague Dr. Csaba Pintér for the pictures in the Figure 1.

875

\section{References}

877 Achard P, Baghour M, Chapple A, Hedden P, Van Der Straeten D, Genschik P, Moritz T, 878 Harberd NP (2007) The plant stress hormone ethylene controls floral transition via DELLA879 dependent regulation of floral meristem-identity genes. Proceedings of the National Academy 880 of Sciences 104:6484-6489

Aida M, Ishida T, Fukaki H, Fujisawa H, Tasaka M (1997) Genes involved in organ separation in Arabidopsis: an analysis of the cup-shaped cotyledon mutant. The Plant Cell 9:841-857 61:1001-1013 
887 Ambawat S, Sharma P, Yadav NR, Yadav RC (2013) MYB transcription factor genes as 888 regulators for plant responses: an overview. Physiology and Molecular Biology of Plants $889 \quad 19: 307-321$

890 Andrews S (2010) FastQC: a quality control tool for high throughput sequence data

891 Arsovski AA, Villota MM, Rowland O, Subramaniam R, Western TL (2009) MUM 892 ENHANCERS are important for seed coat mucilage production and mucilage secretory cell 893 differentiation in Arabidopsis thaliana. Journal of experimental botany 60:2601-2612

894 Bassett IJ, Crompton CW (1975) THE BIOLOGY OF CANADIAN WEEDS.: 11. Ambrosia 895 artemisiifolia L. and A. psilostachya DC. Canadian Journal of Plant Science 55:463-476

896 Baumann K, Perez-Rodriguez M, Bradley D, Venail J, Bailey P, Jin H, Koes R, Roberts K, 897 Martin C (2007) Control of cell and petal morphogenesis by R2R3 MYB transcription factors. 898 Development 134:1691-1701

899 Boavida LC, Qin P, Broz M, Becker JD, McCormick S (2013) Arabidopsis Tetraspanins are 900 Confined to Discrete Expression Domains and Cell Types in Reproductive Tissues and Form 901 Homo-and Hetero-dimers when Expressed in Yeast. Plant physiology:pp. 113.216598

902 Bowman JL, Sakai H, Jack T, Weigel D, Mayer U, Meyerowitz EM (1992) SUPERMAN, a 903 regulator of floral homeotic genes in Arabidopsis. Development 114:599-615

904 Busch A, Horn S, Mühlhausen A, Mummenhoff K, Zachgo S (2011) Corolla monosymmetry: 905 evolution of a morphological novelty in the Brassicaceae family. Molecular biology and 906 evolution 29:1241-1254

907 Ceccato L, Masiero S, Roy DS, Bencivenga S, Ditengou F, Palme K, Simon R, Colombo L 908 (2011) The role of PIN1 in female gametophyte development. Hormonal Network Controlling 909 Ovule Development in Arabidopsis thaliana:21

910 Chandler J (2011) The hormonal regulation of flower development. Journal of Plant Growth 911 Regulation 30:242-254 
912 Chen Q, Atkinson A, Otsuga D, Christensen T, Reynolds L, Drews GN (1999) The Arabidopsis 913 FILAMENTOUS FLOWER gene is required for flower formation. Development 126:2715$914 \quad 2726$

915 Cheng XF, Wang ZY (2005) Overexpression of COL9, a CONSTANS-LIKE gene, delays 916 flowering by reducing expression of CO and FT in Arabidopsis thaliana. The Plant Journal $917 \quad 43: 758-768$

918 Clouse SD (1996) Molecular genetic studies confirm the role of brassinosteroids in plant 919 growth and development. The Plant Journal 10:1-8

920 Coen ES, Meyerowitz EM (1991) The war of the whorls: genetic interactions controlling $921 \quad$ flower development. Nature 353:31

922 Compagnon V, Diehl P, Benveniste I, Meyer D, Schaller H, Schreiber L, Franke R, Pinot F 923 CYP86B1 Is Required for Very Long Chain v-Hydroxyacid and a, v-Dicarboxylic Acid 924 Synthesis in Root and Seed Suberin Polyester1 [W][OA]

925 Conesa A, Götz S, García-Gómez JM, Terol J, Talón M, Robles M (2005) Blast2GO: a 926 universal tool for annotation, visualization and analysis in functional genomics research. 927 Bioinformatics 21:3674-3676

928 Corbesier L, Vincent C, Jang S, Fornara F, Fan Q, Searle I, Giakountis A, Farrona S, Gissot L, 929 Turnbull C (2007) FT protein movement contributes to long-distance signaling in floral 930 induction of Arabidopsis. science 316:1030-1033

931 Crawford BC, Yanofsky MF (2008) The formation and function of the female reproductive 932 tract in flowering plants. Current Biology 18:R972-R978

933 D’aloia M, Bonhomme D, Bouché F, Tamseddak K, Ormenese S, Torti S, Coupland G, 934 935 Périlleux C (2011) Cytokinin promotes flowering of Arabidopsis via transcriptional activation of the FT paralogue TSF. The Plant Journal 65:972-979 
936 Dayan FE, Duke SO (2014) Natural compounds as next generation herbicides. Plant 937 physiology:pp. 114.239061

938 Deen W, Swanton CJ, Hunt LA (2001) A mechanistic growth and development model of 939 common ragweed. Weed science 49:723-731

940 Di Giorgio JP, Bienert GP, Ayub N, Yaneff A, BARBERINI ML, Mecchia MA, Amodeo G, 941 Soto G, MUSCHIETTI JP (2016) Pollen-specific aquaporins NIP4; 1 and NIP4; 2 are required 942 for pollen development and pollination in Arabidopsis thaliana. The Plant Cell:tpc. $943 \quad 00776.02015$

944 Dobritsa AA, Lei Z, Nishikawa S-i, Urbanczyk-Wochniak E, Huhman DV, Preuss D, Sumner 945 LW (2010) LAP5 and LAP6 encode anther-specific proteins with similarity to chalcone 946 synthase essential for pollen exine development in Arabidopsis thaliana. Plant physiology:pp. $947 \quad 110.157446$

948 Dobritsa AA, Nishikawa S-I, Preuss D, Urbanczyk-Wochniak E, Sumner LW, Hammond A, 949 Carlson AL, Swanson RJ (2009) LAP3, a novel plant protein required for pollen development, 950 is essential for proper exine formation. Sexual plant reproduction 22:167

951 Domagalska MA, Schomburg FM, Amasino RM, Vierstra RD, Nagy F, Davis SJ (2007) 952 Attenuation of brassinosteroid signaling enhances FLC expression and delays flowering. 953 Development 134:2841-2850

954 Duan H, Schuler MA (2005) Differential expression and evolution of the Arabidopsis CYP86A 955 subfamily. Plant physiology 137:1067-1081

956 El Kelish A, Zhao F, Heller W, Durner J, Winkler JB, Behrendt H, Traidl-Hoffmann C, Horres 957 R, Pfeifer M, Frank U (2014) Ragweed (Ambrosia artemisiifolia) pollen allergenicity: 958 SuperSAGE transcriptomic analysis upon elevated CO 2 and drought stress. BMC plant 959 biology 14:176 
960 Elliott RC, Betzner AS, Huttner E, Oakes MP, Tucker W, Gerentes D, Perez P, Smyth DR 961 (1996) AINTEGUMENTA, an APETALA2-like gene of Arabidopsis with pleiotropic roles in 962 ovule development and floral organ growth. The Plant Cell 8:155-168

963 Eshed Y, Izhaki A, Baum SF, Floyd SK, Bowman JL (2004) Asymmetric leaf development 964 and blade expansion in Arabidopsis are mediated by KANADI and YABBY activities. 965 Development 131:2997-3006

966 Futamura N, Mori H, Kouchi H, Shinohara K (2000) Male flower-specific expression of genes 967 for polygalacturonase, pectin methylesterase and $\beta$-1, 3-glucanase in a dioecious willow (Salix 968 gilgiana Seemen). Plant and Cell Physiology 41:16-26

969 Gan Y, Liu C, Yu H, Broun P (2007) Integration of cytokinin and gibberellin signalling by 970 Arabidopsis transcription factors GIS, ZFP8 and GIS2 in the regulation of epidermal cell fate. 971 Development 134:2073-2081

972 Gavnholt B, Larsen K (2002) Molecular biology of plant laccases in relation to lignin 973 formation. Physiologia plantarum 116:273-280

974 Gazzani S, Gendall AR, Lister C, Dean C (2003) Analysis of the molecular basis of flowering 975 time variation in Arabidopsis accessions. Plant physiology 132:1107-1114

976 Giarola V, Jung NU, Singh A, Satpathy P, Bartels D (2018) Analysis of pcC13-62 Promoters 977 Predicts a Link between cis-element Variations and Desiccation Tolerance in Linderniaceae. 978 Journal of experimental botany:ery173

979 Gish W, States DJ (1993) Identification of protein coding regions by database similarity search. $980 \quad$ Nature genetics 3:266

981 Gonzalez A, Mendenhall J, Huo Y, Lloyd A (2009) TTG1 complex MYBs, MYB5 and TT2, 982 control outer seed coat differentiation. Developmental biology 325:412-421 
983 Götz S, García-Gómez JM, Terol J, Williams TD, Nagaraj SH, Nueda MJ, Robles M, Talón

984 M, Dopazo J, Conesa A (2008) High-throughput functional annotation and data mining with 985 the Blast2GO suite. Nucleic acids research 36:3420-3435

986

987

988

989

990

991

992

993

994

995

996

997

998

999

1000

1001

1002

1003

1004

1005

1006

1007

Griffiths J, Murase K, Rieu I, Zentella R, Zhang Z-L, Powers SJ, Gong F, Phillips AL, Hedden P, Sun T-p (2006) Genetic characterization and functional analysis of the GID1 gibberellin receptors in Arabidopsis. The Plant Cell 18:3399-3414

Haas BJ, Papanicolaou A, Yassour M, Grabherr M, Blood PD, Bowden J, Couger MB, Eccles D, Li B, Lieber M (2013) De novo transcript sequence reconstruction from RNA-Seq: reference generation and analysis with Trinity. Nature protocols 8

Hakozaki H, Park J-I, Endo M, Takada Y, Kazama T, Takeda Y, Suzuki G, KawagishiKobayashi M, Watanabe M (2008) Expression and developmental function of the 3-ketoacylACP synthase2 gene in Arabidopsis thaliana. Genes \& genetic systems 83:143-152

Hassidim M, Harir Y, Yakir E, Kron I, Green RM (2009) Over-expression of CONSTANSLIKE 5 can induce flowering in short-day grown Arabidopsis. Planta 230:481-491

Hayama R, Yokoi S, Tamaki S, Yano M, Shimamoto K (2003) Adaptation of photoperiodic control pathways produces short-day flowering in rice. Nature 422:719

Helliwell CA, Wood CC, Robertson M, James Peacock W, Dennis ES (2006) The Arabidopsis FLC protein interacts directly in vivo with SOC1 and FT chromatin and is part of a high-molecular-weight protein complex. The Plant Journal 46:183-192

Henry RP (1996) Multiple roles of carbonic anhydrase in cellular transport and metabolism. Annual review of physiology 58:523-538

Higginson T, Li SF, Parish RW (2003) AtMYB103 regulates tapetum and trichome development in Arabidopsis thaliana. The Plant Journal 35:177-192

Hirayama T, Oka A (1992) Novel protein kinase of Arabidopsis thaliana (APK1) that phosphorylates tyrosine, serine and threonine. Plant molecular biology 20:653-662

Peer) reviewing PDF | (2019:01:34305:3:0:NEW 27 Jun 2019) 
1008 Hodgins KA, Lai Z, Nurkowski K, Huang J, Rieseberg LH (2013) The molecular basis of 1009 invasiveness: differences in gene expression of native and introduced common ragweed 1010 (Ambrosia artemisiifolia) in stressful and benign environments. Molecular Ecology 22:249610112510

1012 Honys D, Twell D (2004) Transcriptome analysis of haploid male gametophyte development 1013 in Arabidopsis. Genome biology 5:R85

1014 Horvath, D (2010) Genomics for Weed Science. Current Genomics, 11(1), 47-51.

1015 Irish VF (2010) The flowering of Arabidopsis flower development. The Plant Journal 61:1014$1016 \quad 1028$

1017 Ito T, Takahashi N, Shimura Y, Okada K (1997) A serine/threonine protein kinase gene 1018 isolated by an in vivo binding procedure using the Arabidopsis floral homeotic gene product, 1019 AGAMOUS. Plant and Cell Physiology 38:248-258

1020 Jang S, Marchal V, Panigrahi KC, Wenkel S, Soppe W, Deng XW, Valverde F, Coupland G 1021 (2008) Arabidopsis COP1 shapes the temporal pattern of CO accumulation conferring a 1022 photoperiodic flowering response. The EMBO journal 27:1277-1288

1023 Ji R, Wang H, Xin X, Peng S, Hur Y, Li Z, Feng H (2017) BrEXL6, a GDSL lipase gene of 1024 Brassica rapa, functions in pollen development. Biologia Plantarum 61:685-692

1025 Jung C, Seo JS, Han SW, Koo YJ, Kim CH, Song SI, Nahm BH, Do Choi Y, Cheong J-J (2008) 1026 Overexpression of AtMYB44 enhances stomatal closure to confer abiotic stress tolerance in 1027 transgenic Arabidopsis. Plant physiology 146:623-635

1028 Kaufmann K, Wellmer F, Muiño JM, Ferrier T, Wuest SE, Kumar V, Serrano-Mislata A, 1029 Madueno F, Krajewski P, Meyerowitz EM (2010) Orchestration of floral initiation by 1030 APETALA1. science 328:85-89 
1031

1032

1033

1034

1035

1036

1037

1038

1039

1040

1041

1042

1043

1044

1045

1046

1047

1048

1049

1050

1051

1052

1053

1054
Kazama Y, Fujiwara MT, Koizumi A, Nishihara K, Nishiyama R, Kifune E, Abe T, Kawano S (2009) A SUPERMAN-like gene is exclusively expressed in female flowers of the dioecious plant Silene latifolia. Plant and cell physiology 50:1127-1141

Kazinczi G, Béres I, Novák R, Bíró K, Pathy Z (2008) Common ragweed (Ambrosia artemisiifolia): a review with special regards to the results in Hungary. I. Taxonomy, origin and distribution, morphology, life cycle and reproduction strategy. Herbologia 9:55-91

Klucher KM, Chow H, Reiser L, Fischer RL (1996) The AINTEGUMENTA gene of Arabidopsis required for ovule and female gametophyte development is related to the floral homeotic gene APETALA2. The Plant Cell 8:137-153

Komeda Y (2004) Genetic regulation of time to flower in Arabidopsis thaliana. Annu Rev Plant Biol 55:521-535

Koressaar T, Remm M (2007) Enhancements and modifications of primer design program Primer3. Bioinformatics 23:1289-1291

Krizek BA, Fletcher JC (2005) Molecular mechanisms of flower development: an armchair guide. Nature reviews Genetics 6:688

Langmead B, Trapnell C, Pop M, Salzberg SL (2009) Ultrafast and memory-efficient alignment of short DNA sequences to the human genome. Genome biology 10:R25

Laubinger S, Marchal V, Gentilhomme J, Wenkel S, Adrian J, Jang S, Kulajta C, Braun H, Coupland G, Hoecker U (2006) Arabidopsis SPA proteins regulate photoperiodic flowering and interact with the floral inducer CONSTANS to regulate its stability. Development $133: 3213-3222$

Lee YS, Jeong DH, Lee DY, Yi J, Ryu CH, Kim SL, Jeong HJ, Choi SC, Jin P, Yang J (2010) OsCOL4 is a constitutive flowering repressor upstream of Ehd 1 and downstream of OsphyB. The Plant Journal 63:18-30 
1055 Li B, Dewey CN (2011) RSEM: accurate transcript quantification from RNA-Seq data with or 1056 without a reference genome. BMC bioinformatics 12:323

1057 Li J, Li C, Smith SM (2017) Hormone Metabolism and Signaling in Plants. Academic Press

1058 Li SF, Milliken ON, Pham H, Seyit R, Napoli R, Preston J, Koltunow AM, Parish RW (2009) 1059 The Arabidopsis MYB5 transcription factor regulates mucilage synthesis, seed coat 1060 development, and trichome morphogenesis. The Plant Cell 21:72-89

1061 Liang Y-K, Dubos C, Dodd IC, Holroyd GH, Hetherington AM, Campbell MM (2005) 1062 AtMYB61, an R2R3-MYB transcription factor controlling stomatal aperture in Arabidopsis 1063 thaliana. Current Biology 15:1201-1206

1064 Liscum E, Reed J (2002) Genetics of Aux/IAA and ARF action in plant growth and 1065 development. Plant molecular biology 49:387-400

1066 Liu C, Chen H, Er HL, Soo HM, Kumar PP, Han J-H, Liou YC, Yu H (2008) Direct interaction 1067 of AGL24 and SOC1 integrates flowering signals in Arabidopsis. Development 135:1481$1068 \quad 1491$

1069 Liu C, Jun JH, Dixon RA (2014) MYB5 and MYB14 play pivotal roles in seed coat polymer 1070 biosynthesis in Medicago truncatula. Plant physiology 165:1424-1439

1071 Lloyd D (1984) Gender allocations in outcrossing cosexual plants

1072 Long JA, Barton MK (1998) The development of apical embryonic pattern in Arabidopsis. 1073 Development 125:3027-3035

1074 Lou Y, Xu X-F, Zhu J, Gu J-N, Blackmore S, Yang Z-N (2014) The tapetal AHL family protein 1075 TEK determines nexine formation in the pollen wall. Nature communications 5

1076 Lyons R, Rusu A, Stiller J, Powell J, Manners JM, Kazan K (2015) Investigating the 1077 1078 association between flowering time and defense in the Arabidopsis thaliana-Fusarium oxysporum interaction. PLoS One 10:e0127699 
1079 Makkena S, Lee E, Sack FD, Lamb RS (2012) The R2R3 MYB transcription factors FOUR

1080 LIPS and MYB88 regulate female reproductive development. Journal of experimental botany $1081 \quad 63: 5545-5558$

1082 Makra L, Juhász M, Borsos E, Béczi R (2004) Meteorological variables connected with 1083 airborne ragweed pollen in Southern Hungary. International Journal of Biometeorology 49:37$1084 \quad 47$ DOI $10.1007 / \mathrm{s} 00484-004-0208-4$

1085 Mandel MA, Yanofsky MF (1995) A gene triggering flower formation in Arabidopsis. Nature $1086 \quad 377: 522$

1087 Marsch-Martínez N, Zúñiga-Mayo VM, Herrera-Ubaldo H, Ouwerkerk PB, Pablo-Villa J, 1088 Lozano-Sotomayor P, Greco R, Ballester P, Balanzá V, Kuijt SJ (2014) The NTT transcription 1089 factor promotes replum development in A rabidopsis fruits. The Plant Journal 80:69-81

1090 Matías-Hernández L, Jiang W, Yang K, Tang K, Brodelius PE, Pelaz S (2017) AaMYB1 and 1091 its orthologue AtMYB61 affect terpene metabolism and trichome development in Artemisia 1092 annua and Arabidopsis thaliana. The Plant Journal 90:520-534

Meister RJ, Kotow LM, Gasser CS (2002) SUPERMAN attenuates positive INNER NO OUTER autoregulation to maintain polar development of Arabidopsis ovule outer integuments. Development 129:4281-4289

1096

1097

1098

Michaels SD, Amasino RM (2001) Loss of FLOWERING LOCUS C activity eliminates the late-flowering phenotype of FRIGIDA and autonomous pathway mutations but not responsiveness to vernalization. The Plant Cell 13:935-941

1099

1100

Millar AA, Gubler F (2005) The Arabidopsis GAMYB-like genes, MYB33 and MYB65, are 1101 microRNA-regulated genes that redundantly facilitate anther development. The Plant Cell $17: 705-721$

1102

Mitsuda N, Hiratsu K, Todaka D, Nakashima K, Yamaguchi-Shinozaki K, Ohme-Takagi M 1103 (2006) Efficient production of male and female sterile plants by expression of a chimeric repressor in Arabidopsis and rice. Plant biotechnology journal 4:325-332 
1105

1106

1107

1108

1109

1110

1111

1112

1113

1114

1115

1116

1117

1118

1119

1120

1121

1122

1123

1124

1125

1126

1127

1128

1129

Mortazavi A, Williams BA, McCue K, Schaeffer L, Wold B (2008) Mapping and quantifying mammalian transcriptomes by RNA-Seq. Nature methods 5:621

Murase K, Shigenobu S, Fujii S, Ueda K, Murata T, Sakamoto A, Wada Y, Yamaguchi K, Osakabe Y, Osakabe K (2017) MYB transcription factor gene involved in sex determination in Asparagus officinalis. Genes to Cells 22:115-123

Murashige T, Skoog F (1962) A revised medium for rapid growth and bioassays with tobacco tissue cultures. Physiol Plant 15:473-497

Noda K-i, Glover BJ, Linstead P, Martin C (1994) Flower colour intensity depends on specialized cell shape controlled by a Myb-related transcription factor. Nature 369:661

Pathan M, Keerthikumar S, Ang CS, Gangoda L, Quek CY, Williamson NA, Mouradov D, Sieber OM, Simpson RJ, Salim A (2015) FunRich: An open access standalone functional enrichment and interaction network analysis tool. Proteomics 15:2597-2601

Payne WW (1963) The morphology of the inflorescence of ragweeds (Ambrosia-Franseria: Compositae). American Journal of Botany 50:872-880

Pelaz S, Ditta GS, Baumann E, Wisman E, Yanofsky MF (2000) B and C floral organ identity functions require SEPALLATA MADS-box genes. Nature 405:200

Phan HA, Iacuone S, Li SF, Parish RW (2011) The MYB80 transcription factor is required for pollen development and the regulation of tapetal programmed cell death in Arabidopsis thaliana. The Plant Cell:tpc. 110.082651

Pina C, Pinto F, Feijó JA, Becker JD (2005) Gene family analysis of the Arabidopsis pollen transcriptome reveals biological implications for cell growth, division control, and gene expression regulation. Plant physiology 138:744-756

Putterill J, Robson F, Lee K, Simon R, Coupland G (1995) The CONSTANS gene of Arabidopsis promotes flowering and encodes a protein showing similarities to zinc finger transcription factors. cell 80:847-857

PeerJ reviewing PDF | (2019:01:34305:3:0:NEW 27 Jun 2019) 
1130 Reimann R, Kost B, Dettmer J (2017) TETRASPANINs in Plants. Frontiers in plant science $1131 \quad 8: 545$

1132 Renner SS, Ricklefs RE (1995) Dioecy and its correlates in the flowering plants. American 1133 journal of botany:596-606

1134 Rocheta M, Sobral R, Magalhães J, Amorim MI, Ribeiro T, Pinheiro M, Egas C, Morais1135 Cecílio L, Costa MM (2014) Comparative transcriptomic analysis of male and female flowers 1136 of monoecious Quercus suber. Frontiers in plant science 5:599

1137 Romano JM, Dubos C, Prouse MB, Wilkins O, Hong H, Poole M, Kang KY, Li E, Douglas 1138 CJ, Western TL (2012) AtMYB61, an R2R3-MYB transcription factor, functions as a 1139 pleiotropic regulator via a small gene network. New Phytologist 195:774-786

1140 Samach A, Onouchi H, Gold SE, Ditta GS, Schwarz-Sommer Z, Yanofsky MF, Coupland G 1141 (2000) Distinct roles of CONSTANS target genes in reproductive development of Arabidopsis. 1142 Science 288:1613-1616

1143 Sanderfoot AA, Kovaleva V, Bassham DC, Raikhel NV (2001) Interactions between syntaxins 1144 identify at least five SNARE complexes within the Golgi/prevacuolar system of the 1145 Arabidopsis cell. Molecular Biology of the Cell 12:3733-3743

1146 Sato Y, Wuli B, Sederoff R, Whetten R (2001) Molecular cloning and expression of eight 1147 laccase cDNAs in loblolly pine (Pinus taeda). Journal of Plant Research 114:147-155

1148 Searle I, He Y, Turck F, Vincent C, Fornara F, Kröber S, Amasino RA, Coupland G (2006) 1149 The transcription factor FLC confers a flowering response to vernalization by repressing 1150 meristem competence and systemic signaling in Arabidopsis. Genes \& development 20:8981151912

1152 Sheoran IS, Sproule KA, Olson DJ, Ross AR, Sawhney VK (2006) Proteome profile and 1153 functional classification of proteins in Arabidopsis thaliana (Landsberg erecta) mature pollen. 1154 Sexual Plant Reproduction 19:185-196 
1155 Siegfried KR, Eshed Y, Baum SF, Otsuga D, Drews GN, Bowman JL (1999) Members of the 1156 YABBY gene family specify abaxial cell fate in Arabidopsis. Development 126:4117-4128

1157 Simpson GG, Dean C (2002) Arabidopsis, the Rosetta stone of flowering time? Science $1158 \quad 296: 285-289$

1159 Singer BD, Ziska LH, Frenz DA, Gebhard DE, Straka JG (2005) Increasing Amb a 1 content 1160 in common ragweed (Ambrosia artemisiifolia) pollen as a function of rising atmospheric $\mathrm{CO} 2$ concentration. Functional Plant Biology 32:667-670

1162 Smith KS, Ferry JG (2000) Prokaryotic carbonic anhydrases. FEMS microbiology reviews $1163 \quad 24: 335-366$

1164 Song YH, Ito S, Imaizumi T (2010) Similarities in the circadian clock and photoperiodism in 1165 plants. Current opinion in plant biology 13:594-603

1166 Song YH, Ito S, Imaizumi T (2013) Flowering time regulation: photoperiod-and temperature$1167 \quad$ sensing in leaves. Trends in plant science 18:575-583

1168 Sudre D, Gutierrez-Carbonell E, Lattanzio G, Rellán-Álvarez R, Gaymard F, Wohlgemuth G, 1169 Fiehn O, Álvarez-Fernández A, Zamarreño AM, Bacaicoa E (2013) Iron-dependent 1170 modifications of the flower transcriptome, proteome, metabolome, and hormonal content in an 1171 Arabidopsis ferritin mutant. Journal of experimental botany 64:2665-2688

1172 Sung S, Amasino RM (2004) Vernalization in Arabidopsis thaliana is mediated by the PHD 1173 finger protein VIN3. Nature 427:159

1174 Taiz L, Zeiger E, Møller IM, Murphy A (2015) Plant physiology and development. Sinauer 1175 Associates, Incorporated

1176 Tashian RE (1989) The carbonic anhydrases: widening perspectives on their evolution, 1177 expression and function. Bioessays 10:186-192 
1178

1179

1180

1181

1182

1183

1184

1185

1186

1187

1188

1189

1190

1191

1192

1193

1194

1195

1196

1197

1198

1199

1200

1201

1202 van der Krol AR, Brunelle A, Tsuchimoto S, Chua N-H (1993) Functional analysis of petunia floral homeotic MADS box gene pMADS1. Genes \& Development 7:1214-1228

Untergrasser A, Cutcutache I, Koressaar T, Ye J, Faircloth B, Remm M, Rozen S (2012) Primer3-new capabilities and interfaces. Nucleic Acids Research

Villanueva JM, Broadhvest J, Hauser BA, Meister RJ, Schneitz K, Gasser CS (1999) INNER NO OUTER regulates abaxial-adaxial patterning in Arabidopsis ovules. Genes \& Development 13:3160-3169

Virág E, Hegedűs G, Barta E, Nagy E, Mátyás K, Kolics B, Taller J (2016) Illumina Sequencing of Common (Short) Ragweed (Ambrosia artemisiifolia L.) Reproductive Organs and Leaves. Frontiers in plant science 7

Wang H, Schauer N, Usadel B, Frasse P, Zouine M, Hernould M, Latché A, Pech J-C, Fernie AR, Bouzayen M (2009) Regulatory features underlying pollination-dependent andindependent tomato fruit set revealed by transcript and primary metabolite profiling. The Plant Cell 21:1428-1452

Wayne P, Foster S, Connolly J, Bazzaz F, Epstein P (2002) Production of allergenic pollen by ragweed (Ambrosia artemisiifolia L.) is increased in CO2-enriched atmospheres. Annals of Allergy, Asthma \& Immunology 88:279-282

Weigel D, Nilsson O (1995) A developmental switch sufficient for flower initiation in diverse plants. Nature 377:495

Wigge PA, Kim MC, Jaeger KE, Busch W, Schmid M, Lohmann JU, Weigel D (2005) Integration of spatial and temporal information during floral induction in Arabidopsis. Science 309:1056-1059

Xu J, Yang C, Yuan Z, Zhang D, Gondwe MY, Ding Z, Liang W, Zhang D, Wilson ZA (2010) The ABORTED MICROSPORES regulatory network is required for postmeiotic male reproductive development in Arabidopsis thaliana. The Plant Cell 22:91-107 
1203 Yang C, Xu Z, Song J, Conner K, Barrena GV, Wilson ZA (2007) Arabidopsis MYB26/MALE 1204 STERILE35 regulates secondary thickening in the endothecium and is essential for anther 1205 dehiscence. The Plant Cell 19:534-548

1206 Yang X, Pang H-B, Liu B-L, Qiu Z-J, Gao Q, Wei L, Dong Y, Wang Y-Z (2012) Evolution of 1207 double positive autoregulatory feedback loops in CYCLOIDEA2 clade genes is associated 1208 with the origin of floral zygomorphy. The Plant Cell 24:1834-1847

1209 Yu J-W, Rubio V, Lee N-Y, Bai S, Lee S-Y, Kim S-S, Liu L, Zhang Y, Irigoyen ML, Sullivan 1210 JA (2008) COP1 and ELF3 control circadian function and photoperiodic flowering by 1211 regulating GI stability. Molecular cell 32:617-630

1212 Zha H-G, Liu T, Zhou J-J, Sun H (2013) MS-desi, a desiccation-related protein in the floral 1213 nectar of the evergreen velvet bean (Mucuna sempervirens Hemsl): molecular identification 1214 and characterization. Planta 238:77-89

1215 Zhang J, Liu B, Li M, Feng D, Jin H, Wang P, Liu J, Xiong F, Wang J, Wang H-B (2015) The 1216 bHLH transcription factor bHLH104 interacts with IAA-LEUCINE RESISTANT3 and 1217 modulates iron homeostasis in Arabidopsis. The Plant Cell:tpc. 114.132704

1218 Zhu J-Y, Sae-Seaw J, Wang Z-Y (2013) Brassinosteroid signalling. Development 140:1615$1219 \quad 1620$

1220 Zhu J, Lou Y, Xu X, Yang ZN (2011) A genetic pathway for tapetum development and 1221 function in Arabidopsis. Journal of integrative plant biology 53:892-900 


\section{Figure 1}

Developmental phenophases of female and male flowers used for RNA seq.

Symbols: Female flowers (F) and male flowers (M). For RNA extraction for $A$. artemisiifolia reference sequence the pool of $F(A-I)$ and $M(J-Q)$ of wild growing samples were performed, separately. In order to obtain pistillate specific transcriptomes during floral organ formation, RNA extraction were performed from in vitro samples from $F(A-C)$ and $F(G-I)$, wild growing samples from M (J-L) and M (P-Q) such as early and late developmental stages. Photo: Csaba Pintér 


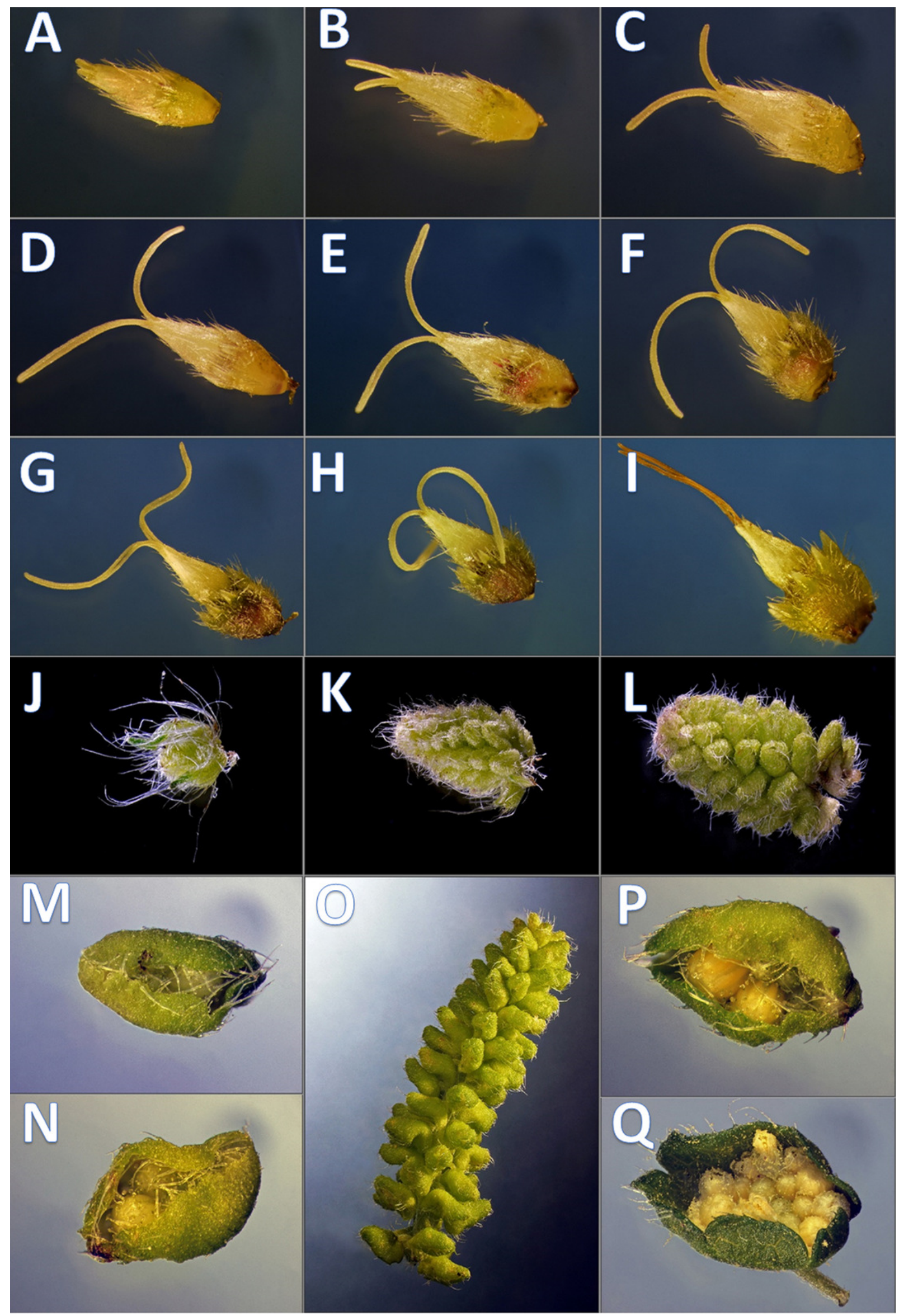




\section{Figure 2}

Assembly strategy of $A$. artemisiifolia floral transcript datasets.

As a first step a de novo Trinity assembly of combined read set of male (M), female (F) and leaf $(\mathrm{L})$ of $A$. artemisiifolia wild growing plants was performed to get a reference transcriptome that represent both vegetative and generative organ transcripts in different developmental stages. Separately two set of reads representing two classes of $\mathrm{F}$ development such as early (1F) and late (2F) stages were generated from sterile in vitro plants. In order to perform differential expression analysis of each five sample, cleaned read sets of $\mathrm{M}, \mathrm{L}, \mathrm{F}, \mathrm{IF}$ and $2 \mathrm{~F}$ were assembled by using bowtie2 reference guided algorithm aligning reads to the $A$. artemisiifolia reference transcriptome. Focusing on the female floral expression pattern in various developmental stages we determined the $F$ unique transcripts collecting the whole female tissue specific contig set. After that $1 \mathrm{~F}$ and $2 \mathrm{~F}$ unique transcripts were clustered aligning them to the $\mathrm{F}$ contig set. In the second step Trinity de novo assembly were performed using $1 \mathrm{~F}$ and $2 \mathrm{~F}$ cleaned reads to get $1 \mathrm{~F}$ and $2 \mathrm{~F}$ specific contigs. In order to filter exactly the $1 \mathrm{~F}$ and $2 \mathrm{~F}$ specific transcripts, and characteristic transcription pattern to both developmental classes we aligned the $1 \mathrm{~F}$ and $2 \mathrm{~F}$ unique transcripts to $1 \mathrm{~F}$ and $2 \mathrm{~F}$ de novo Trinity contigs used Blastn algorithm. Thus filtered sequences were annotated using Blastx search and Blast2Go high throughput blast against the NCBI nr protein database. Transcript data sets of de novo Trinity assembly of combined F-L-M as A. artemisiifolia refseq and separately $1 \mathrm{~F}$ and $2 \mathrm{~F}$ were deposited in the NCBI TSA database with the accession number shown in the Figure. 


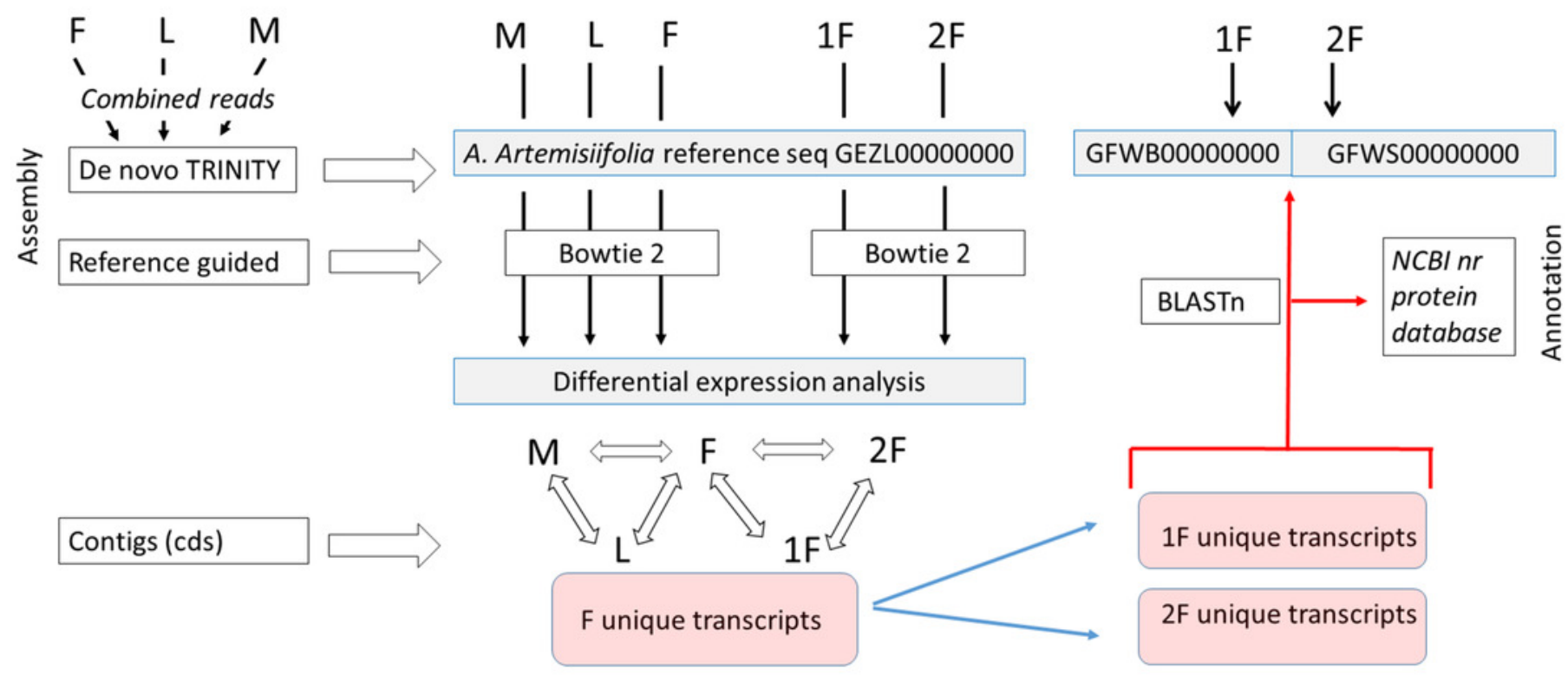




\section{Figure 3}

Investigated genes representing different floral regulatory pathways in F, M, L libraries.

These genes were selected for characterize genetic events during male and female floral architecture formation and floral meristem initiation during vegetative growth such as photoperiodic, vernalisation and meristem identity genes. Normalized expression of selected genes were performed digitally and expression values were compared with each libraries $F$, M, L with HiSeq2000 technology. 


\begin{tabular}{|c|c|c|c|c|c|}
\hline & Pathway & Gene & $\mathbf{F}$ & L & M \\
\hline & Gibberellin & GID1A & 83,32 & 353,76 & 160,19 \\
\hline & & GID1B & 15,85 & 349,98 & 31,58 \\
\hline & & GID2 & 40,18 & 187,02 & 73,88 \\
\hline & & GAI & 36,01 & 540,92 & 73,89 \\
\hline & & Ga2ox8 & 22,63 & 25,41 & 8,01 \\
\hline & & Ga2ox1 & 8,44 & 86,51 & 39,89 \\
\hline & & Ga2ox3 & 0,44 & 28,07 & 16,49 \\
\hline & & Ga3ox1 & 0 & 67,16 & 9,65 \\
\hline & & Сyp450 & 108,23 & 995,33 & 170,72 \\
\hline \multirow{25}{*}{ 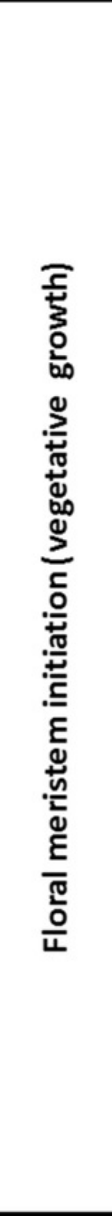 } & \multirow[t]{6}{*}{ Photoperiodic } & PHYB & 22,10 & 150,76 & 53,89 \\
\hline & & PHYA & 2,36 & 5,76 & 8,03 \\
\hline & & CRY1 & 14,37 & 533,24 & 38,92 \\
\hline & & COP1 & 8,16 & 236,62 & 33,68 \\
\hline & & CO & 9,52 & 2168,15 & 98,54 \\
\hline & & $S P A$ & 2,20 & 68,42 & 5,11 \\
\hline & \multirow[t]{8}{*}{ Vernalization } & CSTF77 & 5,48 & 84,59 & 19,67 \\
\hline & & CSTF64 & 3,72 & 81,72 & 17,07 \\
\hline & & VIP6 & 5,56 & 94,84 & 22,94 \\
\hline & & VIP5 & 11,96 & 181,12 & 41,91 \\
\hline & & VIP4 & 13,34 & 189,45 & 61,25 \\
\hline & & VIP3 & 41,96 & 98,16 & 61,81 \\
\hline & & VIN3 & 0,00 & 313,45 & 10,81 \\
\hline & & VRN1 & 9,09 & 41,66 & 27,08 \\
\hline & \multirow{11}{*}{$\begin{array}{c}\text { Flower } \\
\text { development }\end{array}$} & $E M B F 2$ & 18,25 & 80,38 & 47,20 \\
\hline & & $C A L$ & 114,80 & 0,00 & 1,94 \\
\hline & & SOC1 & 0,00 & 0,00 & 0,00 \\
\hline & & $F T$ & 0,00 & 1487,94 & 56,17 \\
\hline & & $F D$ & 0,00 & 10,40 & 16,05 \\
\hline & & $L M I 2$ & 6,75 & 7,12 & 41,52 \\
\hline & & FUL & 6,17 & 103,31 & 75,64 \\
\hline & & $S V P$ & 12,51 & 31,71 & 7,55 \\
\hline & & TFL1 & 0,00 & 1461,09 & 56,95 \\
\hline & & $S P L 3$ & 122,02 & 0,00 & 293,90 \\
\hline & & SPL1 & 80,85 & 29,85 & 96,28 \\
\hline \multirow{13}{*}{ 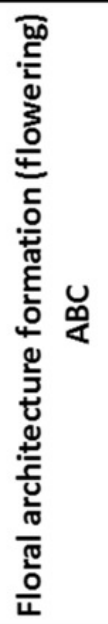 } & $A$ & $A P 2$ & 0,00 & 110,81 & 1,98 \\
\hline & $A$ & $A P 1$ & 162,27 & 1,93 & 6,11 \\
\hline & B & $P I$ & 0,00 & 0,00 & 385,99 \\
\hline & B & AP3 3 & 20,34 & 7,84 & 150,85 \\
\hline & B & AP3 2 & 0,00 & 0,00 & 187,24 \\
\hline & B & AP3 1 & 5,31 & 0,00 & 80,51 \\
\hline & C & $A G$ & 45,64 & 1,10 & 187,59 \\
\hline & $E$ & SEP4 & 111,34 & 1,10 & 43,86 \\
\hline & $E$ & SEP3 2 & 175,89 & 98,35 & 271,40 \\
\hline & $E$ & SEP3 1 & 78,92 & 7,52 & 59,01 \\
\hline & $E$ & SEP 22 & 84,95 & 98,55 & 66,94 \\
\hline & $E$ & SEP2 & 105,90 & 1,90 & 32,51 \\
\hline & $E$ & SEP1 & 30,22 & 2,50 & 72,73 \\
\hline
\end{tabular}


Figure 4

Investigated genes representing different floral regulatory pathways in $1 \mathrm{~F}, 2 \mathrm{~F}$ and $1 \mathrm{M}$ $2 \mathrm{M}$ libraries.

The normalized expression values of flower development genes has also been studied in libraries 1F, 2F, 1M, 2M with NextSeq 500 technology derived from in vitro and wild growing plant materials. 


\begin{tabular}{|c|c|c|c|c|c|c|}
\hline & Pathway & Gene & 1F & 2F & $1 \mathrm{M}$ & 2M \\
\hline & Gibberellin & GIDIA & 718,72 & 818,45 & 371,26 & 323,73 \\
\hline & & GID1B & 60,25 & 188,07 & 77,34 & 64,89 \\
\hline & & GID2 & 520,22 & 462,20 & 228,17 & 236,33 \\
\hline & & GAI & 306,10 & 295,90 & 407,41 & 420,34 \\
\hline & & Ga20x8 & 207,07 & 220,68 & 37,58 & 33,71 \\
\hline & & Ga2ox1 & 83,26 & 48,55 & 147,25 & 157,31 \\
\hline & & Ga2ox3 & 18,87 & 15,10 & 41,42 & 69,05 \\
\hline & & Ga3ox1 & 0 & 0 & 162,01 & 177,76 \\
\hline & & Cyp 450 & 139,44 & 270,7 & 1252,2 & 3499,78 \\
\hline \multirow{25}{*}{ 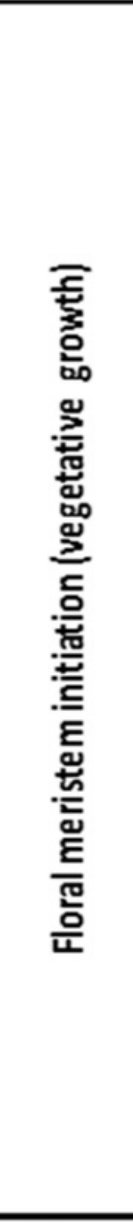 } & \multirow[t]{6}{*}{ Photoperiodic } & PHYB & 298,71 & 244,20 & 224,23 & 209,08 \\
\hline & & PHYA & 57,85 & 41,89 & 77,83 & 80,84 \\
\hline & & CRY1 & 230,51 & 424,48 & 95,38 & 102,69 \\
\hline & & COP1 & 74,27 & 64,88 & 102,09 & 96,59 \\
\hline & & $\mathrm{CO}$ & 113,99 & 118,43 & 443,84 & 451,84 \\
\hline & & $S P A$ & 20,27 & 15,92 & 20,98 & 19,29 \\
\hline & \multirow[t]{8}{*}{ Vernalization } & CSTF77 & 126,07 & 114,60 & 140,87 & 130,34 \\
\hline & & CSTF64 & 91,56 & 67,24 & 55,48 & 55,49 \\
\hline & & VIPG & 169,16 & 168,28 & 106,73 & 109,52 \\
\hline & & VIPS & 153,24 & 177,16 & 144,57 & 151,45 \\
\hline & & VIP4 & 426,24 & 492,56 & 388,79 & 392,59 \\
\hline & & VIP3 & 218,86 & 156,07 & 137,23 & 128,29 \\
\hline & & VIN3 & 8,61 & 14,47 & 48,01 & 49,08 \\
\hline & & VRN1 & 177,92 & 273,02 & 100,43 & 103,99 \\
\hline & \multirow{11}{*}{$\begin{array}{c}\text { Flower } \\
\text { development }\end{array}$} & $E M B F 2$ & 143,32 & 128,64 & 114,59 & 107,31 \\
\hline & & $C A L$ & 2076,87 & 3059,01 & 15,11 & 13,49 \\
\hline & & SOC1 & 44,62 & 19,54 & 0 & o \\
\hline & & $F T$ & 7,21 & 0,00 & 295,35 & 258,03 \\
\hline & & $F D$ & 12,45 & 10,82 & 20,15 & 14,16 \\
\hline & & $L M I 2$ & 73,47 & 29,53 & 188,22 & 208,34 \\
\hline & & FUL & 81,42 & 70,65 & 316,24 & 298,81 \\
\hline & & $S V P$ & 56,48 & 49,01 & 24,26 & 15,75 \\
\hline & & TFLI & 7,69 & 0,00 & 286,143 & 269,34 \\
\hline & & SPL3 & 364,35 & 602,39 & 635,25 & 686,31 \\
\hline & & SPLI & 6,64 & 17,96 & 499,06 & 513,67 \\
\hline \multirow{13}{*}{ 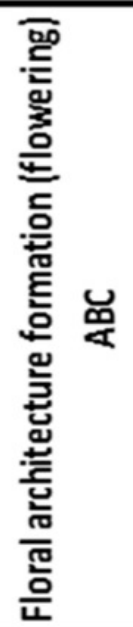 } & $A$ & $A P 2$ & 0,00 & 0,00 & 4,97 & 5,59 \\
\hline & $A$ & $A P 1$ & 2435,41 & 3532,78 & 11,15 & 10,49 \\
\hline & B & $P I$ & 4,29 & 3,19 & 2370,99 & 2571,13 \\
\hline & $B$ & $A P 33$ & 229,98 & 247,66 & 994,37 & 1106,86 \\
\hline & B & AP3 2 & 163,94 & 223,67 & 1724,01 & 1757,56 \\
\hline & B & $A P 31$ & 285,63 & 293,35 & 263,7 & 238,34 \\
\hline & $C$ & $A G$ & 869,62 & 738,51 & 967,73 & 919,1 \\
\hline & $E$ & SEP4 & 1285,10 & 1166,06 & 209,46 & 237,09 \\
\hline & $E$ & SEP3 2 & 3073,76 & 1974,46 & 1031,59 & 1097,51 \\
\hline & $E$ & SEP3 1 & 661,21 & 499,63 & 215,78 & 217,48 \\
\hline & $E$ & SEP 22 & 1229,70 & 1530,87 & 278,9 & 276,62 \\
\hline & $E$ & SEP 2 & 2060,41 & 1628,81 & 222,62 & 238,75 \\
\hline & $\boldsymbol{E}$ & SEP1 & 732,25 & 534,94 & 915,63 & 964,9 \\
\hline
\end{tabular}


Figure 5

Venn diagram indicating the number of exclusive and shared transcripts in wild growing male $(M)$, female $(F)$ flowers and leaf $(L)$ samples.

The datasets were extracted from Trinotate heat map and visualized with FunRich. The comparison and distribution of transcripts were specified according the expressed sequences in groups of leaf versus (vs) female, male vs female and leaf vs male transcriptomes of $A$. artemisiifolia reference GEZL00000000. The SQL queries for organ specific unique transcripts resulted in 4549 (unique M), 1691 (unique F) and 4267 (unique L).

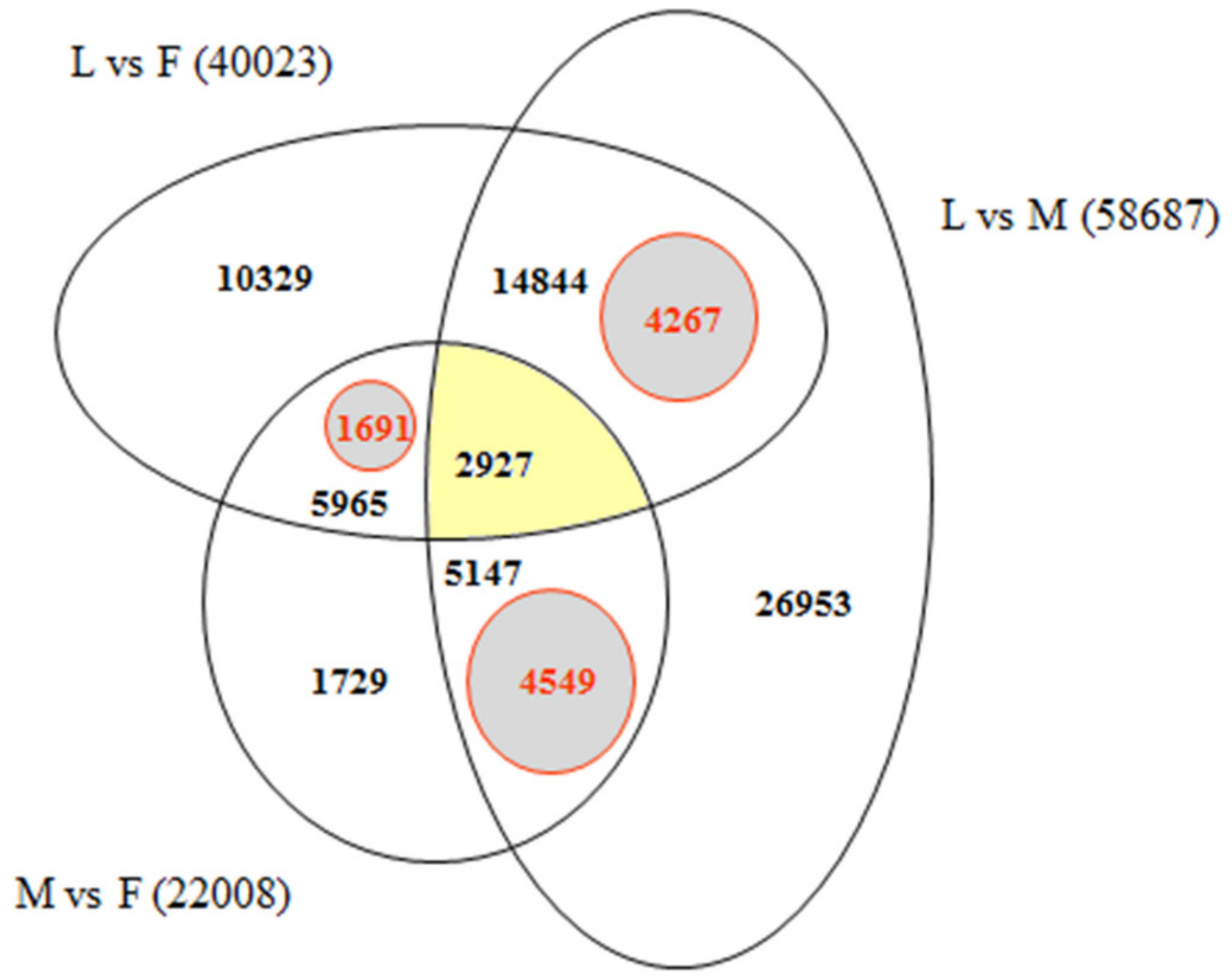


Figure 6

Comparative analysis of male specific (A) and female specific (B) gene expression.

RT-qPCR analysis were determined as $\log _{10}$ relative fold. Tables inserted in the diagram show the real values of expression measured by RT-qPCR. 

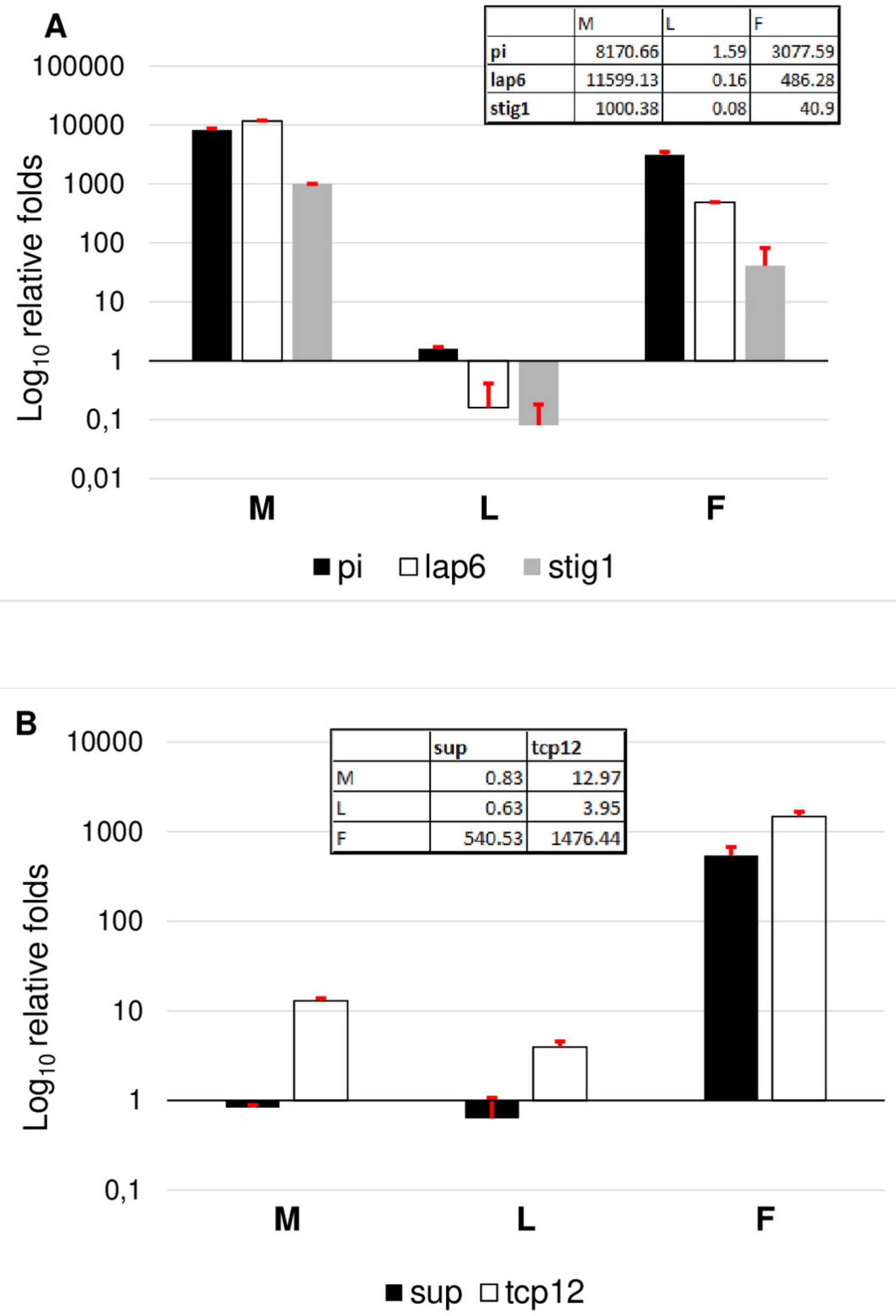


\section{Figure 7}

In vitro cultivated $A$. artemisiifolia individuals.

During the life cycle of in vitro plant the female flowers were appeared earlier and in greater amounts (A). Appearence of male inflorescences were minimal (B) which is the opposite phenomena that may observed under wild-growing conditions. Arrows show the appearance of dense pistillate and spars staminate flowers in vitro.

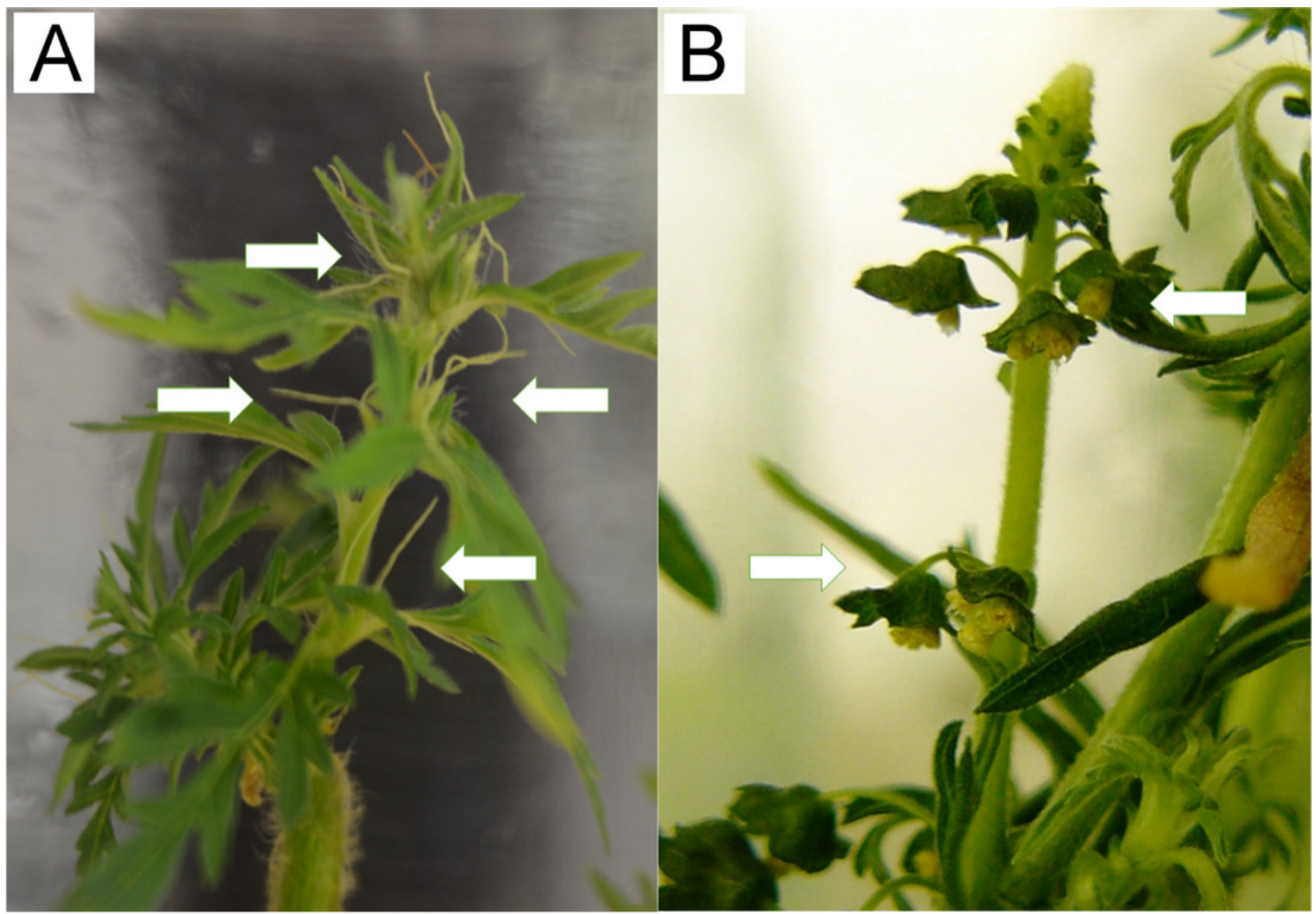




\section{Figure 8}

Expression differences between ABCE genes.

Normalized expression rate were determined by using Trinotate (A) and RPKM (B). A. The highest expression of $A P 1$ were confirmed in female flowers $(F)$ and exclusive expression of $P I$ and AP3 in male flowers (M). B. During female flower development the same trend might be observed. The male characteristic AP2 and PI were not expressed, hovewer AP3 2 showed minimal expression. The highest expression of $A P 1$ were detected in both $1 \mathrm{~F}$ and $2 \mathrm{~F}$ phenophases. 
A Expression of $\mathrm{ABCE}$ genes in $\mathrm{M}, \mathrm{F}$ and $\mathrm{L}$ libraries

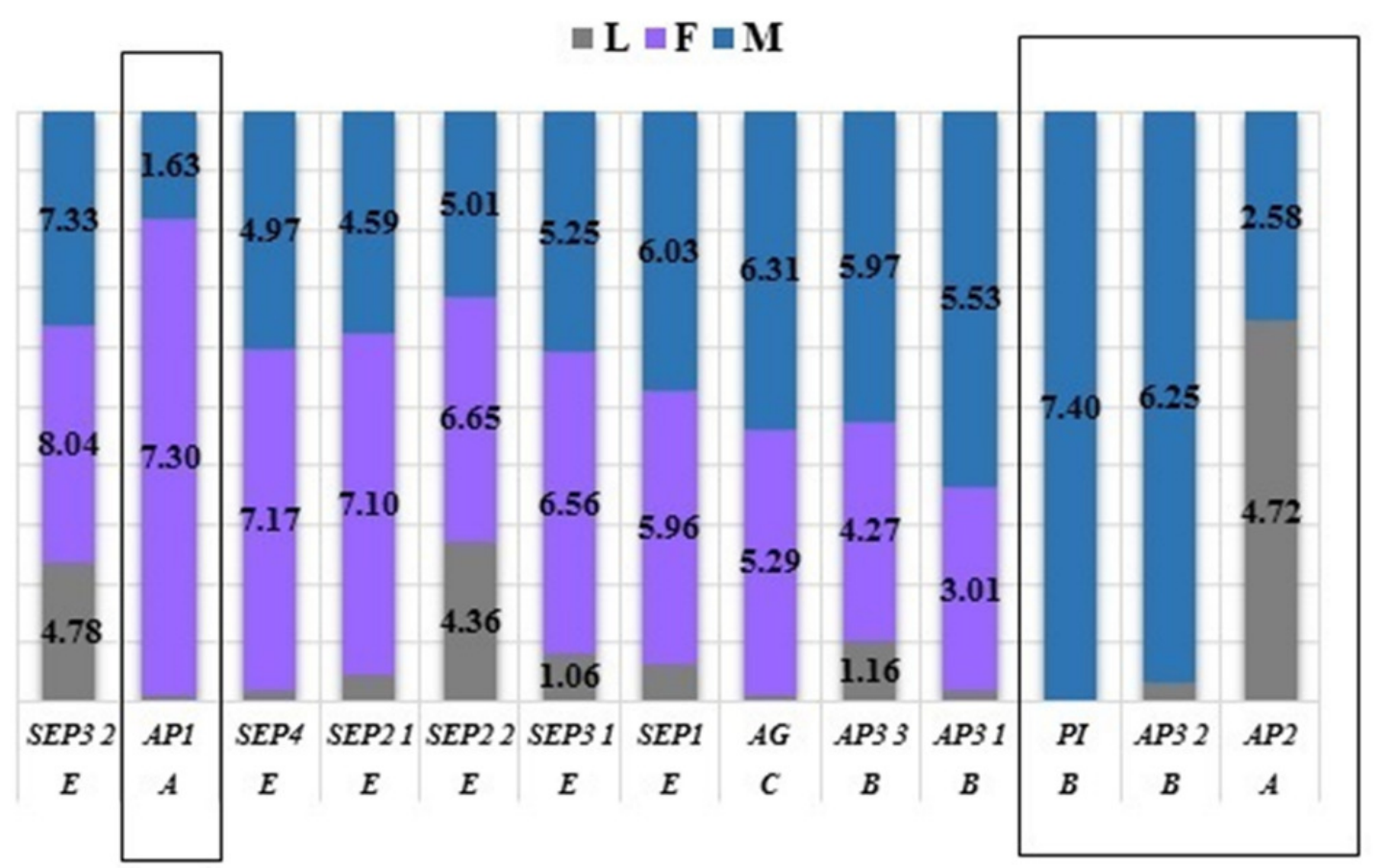

B Expression rate of $\mathrm{ABCE}$ genes during female flower development

$\%$

$1 \mathrm{~F} \square 2 \mathrm{~F} \square$

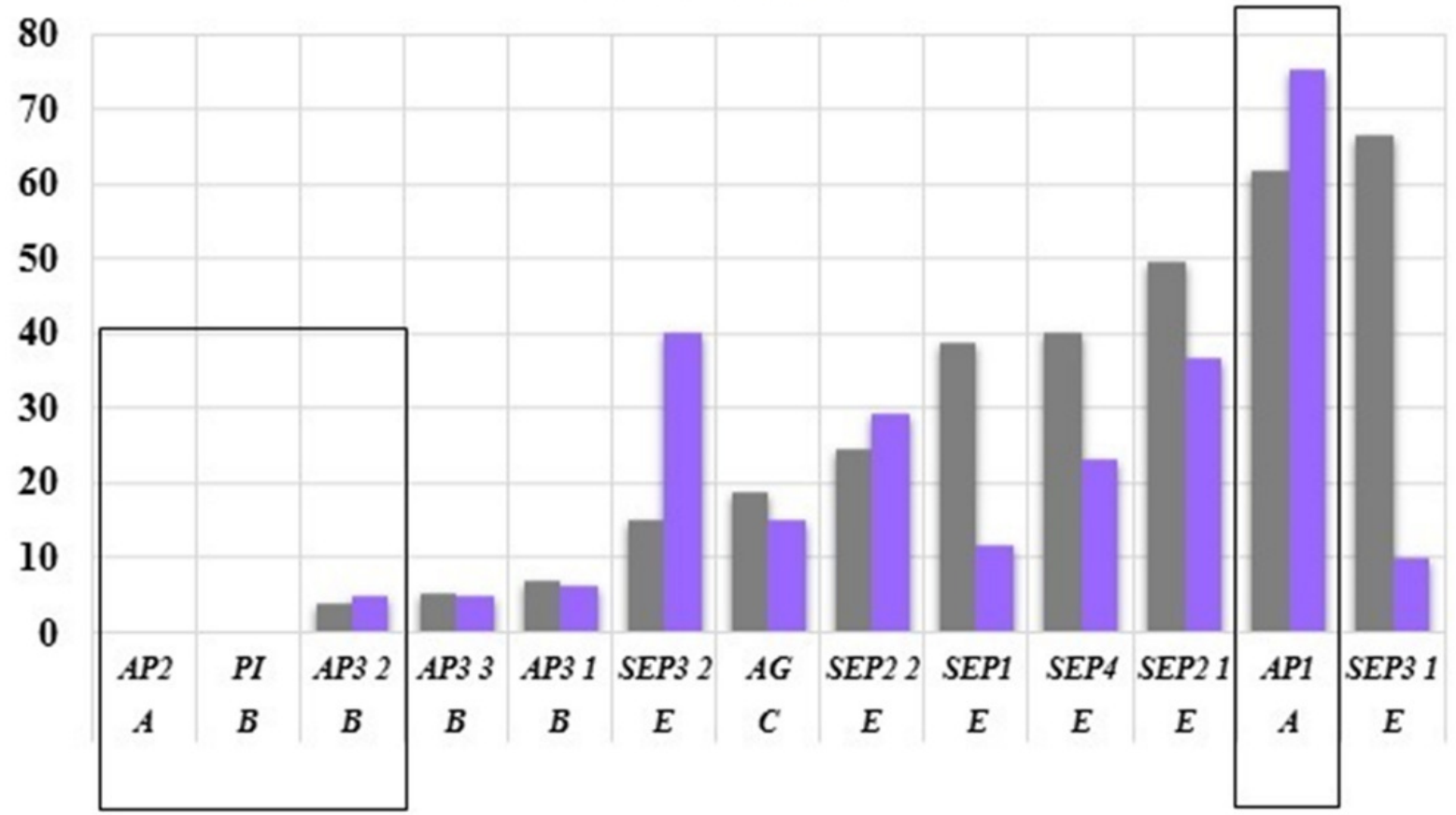




\section{Table 1 (on next page)}

Function and expression values of male candidate genes selected to validate floral transcriptomes.

STIG1 were found as male candidate instead of female as described in other species. 


\begin{tabular}{|c|c|c|c|c|c|c|}
\hline \multirow{2}{*}{$\begin{array}{l}\text { Gene } \\
\text { homolog }\end{array}$} & \multirow{2}{*}{$\begin{array}{l}\text { Encoded } \\
\text { protein }\end{array}$} & \multirow{2}{*}{$\begin{array}{l}\text { Function } \\
\text { (UniProt description) }\end{array}$} & \multirow[t]{2}{*}{ References } & \multicolumn{3}{|c|}{$\begin{array}{l}\text { Normalized } \\
\text { expression }\end{array}$} \\
\hline & & & & $\mathbf{M}$ & $\mathbf{L}$ & $\mathbf{F}$ \\
\hline \multicolumn{7}{|c|}{ Male candidate genes } \\
\hline$A M S$ & $\begin{array}{l}\text { Transcription } \\
\text { factor EN } 48\end{array}$ & $\begin{array}{l}\text { Regulates male } \\
\text { fertility and pollen } \\
\text { differentiation. }\end{array}$ & $\begin{array}{l}\text { Xu et al, 2010; } \\
\text { Lou et al, } 2014\end{array}$ & 8,91 & 0,44 & 0,52 \\
\hline$L A P 3$ & $\begin{array}{l}\text { Protein } \\
\text { strictosidine } \\
\text { synthase-like } \\
13\end{array}$ & $\begin{array}{l}\text { Required for proper } \\
\text { exine formation } \\
\text { during pollen } \\
\text { development }\end{array}$ & Dobritsa et al, 2009 & 9,61 & 0,21 & 0 \\
\hline$L A P 5$ & $\begin{array}{l}\text { Type III } \\
\text { polyketide } \\
\text { synthase B } \\
\end{array}$ & \multirow{2}{*}{$\begin{array}{l}\text { Required for pollen } \\
\text { development and } \\
\text { biosynthesis of pollen } \\
\text { fatty acids }\end{array}$} & \multirow{2}{*}{$\begin{array}{l}\text { Dobritsa et al, 2010; } \\
\text { Rocheta et al, } 2014\end{array}$} & 6,65 & 0 & 0 \\
\hline LAP6 & $\begin{array}{l}\text { Type III } \\
\text { polyketide } \\
\text { synthase A }\end{array}$ & & & 8,39 & 0 & 0 \\
\hline STIG1 & $\begin{array}{l}\text { Stigma- } \\
\text { specific } \\
\text { protein }\end{array}$ & $\begin{array}{l}\text { Involved in the } \\
\text { temporal regulation of } \\
\text { the exudate secretion } \\
\text { onto the stigma }\end{array}$ & Rocheta et al, 2014 & 3,12 & 0 & 0 \\
\hline$P G 1$ & $\begin{array}{l}\text { Polygalacturon } \\
\text { ase } 1 \text { beta-like } \\
\text { protein } 2\end{array}$ & $\begin{array}{l}\text { Involved in cell size } \\
\text { determination. }\end{array}$ & Futamura et al, 2000 & 3,42 & 0 & 0 \\
\hline$P G 2$ & $\begin{array}{l}\text { Polygalacturon } \\
\text { ase } 1 \text { beta-like } \\
\text { protein } 3\end{array}$ & $\begin{array}{l}\text { Involved in cell size } \\
\text { determination. May } \\
\text { serve as a chaperone } \\
\text { for expansins through } \\
\text { the secretory pathway. }\end{array}$ & Futamura et al, 2000 & 4,71 & 0,43 & 0 \\
\hline$P M E$ & Pectinesterase & $\begin{array}{l}\text { Plays an important } \\
\text { role in growth of } \\
\text { pollen tubes. Involved } \\
\text { in anther development } \\
\text { and play role in } \\
\text { tapetum and pollen } \\
\text { development. }\end{array}$ & Futamura et al, 2000 & 6,33 & 0,42 & 0 \\
\hline MSE1 & $\begin{array}{l}\text { Putative } \\
\text { duplicated } \\
\text { homeodomain- } \\
\text { like } \\
\text { superfamily } \\
\text { protein }\end{array}$ & $\begin{array}{l}\text { Exhibits tight linkage } \\
\text { with the Y } \\
\text { chromosome, specific } \\
\text { expression in early } \\
\text { anther development } \\
\text { and loss of function } \\
\text { on the X chromosome. }\end{array}$ & Murase et al, 2017 & 7,12 & 0,41 & 0 \\
\hline
\end{tabular}




\section{Table 2 (on next page)}

Function and expression values of female candidate genes selected to validate floral transcriptomes.

Genes marked with * were selected based on our filtering by using SQL Server Manager Studio (see Materials and methods). 


\begin{tabular}{|c|c|c|c|c|c|c|}
\hline \multirow{2}{*}{$\begin{array}{l}\text { Gene } \\
\text { homolog }\end{array}$} & \multirow{2}{*}{$\begin{array}{l}\text { Encoded } \\
\text { protein }\end{array}$} & \multirow{2}{*}{$\begin{array}{l}\text { Function } \\
\text { (UniProt description) }\end{array}$} & \multirow[t]{2}{*}{ References } & \multicolumn{3}{|c|}{$\begin{array}{l}\text { Normalized } \\
\text { expression }\end{array}$} \\
\hline & & & & $\mathbf{M}$ & $\mathbf{L}$ & $\mathbf{F}$ \\
\hline \multicolumn{7}{|c|}{ Female candidate genes } \\
\hline$Y A B 1$ & $\begin{array}{l}\text { Axial regulator } \\
\text { YABBY } 1\end{array}$ & $\begin{array}{l}\text { In gynoecium, } \\
\text { expressed in the } \\
\text { abaxial cell layers } \\
\text { differentiating into the } \\
\text { valves meristem } \\
\text { development. }\end{array}$ & $\begin{array}{l}\text { Siegfried et al, } \\
1999\end{array}$ & 1,78 & 0,51 & 6,51 \\
\hline$Y A B 4$ & $\begin{array}{l}\text { Protein INNER } \\
\text { NO OUTER }\end{array}$ & $\begin{array}{l}\text { Essential for the } \\
\text { formation and the } \\
\text { abaxial-adaxial } \\
\text { asymmetric growth of } \\
\text { the ovule outer } \\
\text { integument. }\end{array}$ & $\begin{array}{l}\text { Villanueva et } \\
\text { al, 1999; } \\
\text { Meister et al, } \\
2002\end{array}$ & 2,61 & 2,73 & 7,05 \\
\hline$A N T$ & $\begin{array}{l}\text { AP2-like } \\
\text { ethylene- } \\
\text { responsive } \\
\text { transcription } \\
\text { factor ANT }\end{array}$ & $\begin{array}{l}\text { Transcription } \\
\text { activator. Required for } \\
\text { the initiation and } \\
\text { growth of ovules } \\
\text { integumenta, and for } \\
\text { the development of } \\
\text { female gametophyte. }\end{array}$ & $\begin{array}{l}\text { Klucher et al, } \\
\text { 1996;Elliot et } \\
\text { al, 1996;Long } \\
\text { and Barton, } \\
1998\end{array}$ & 2,04 & 0,35 & 7,91 \\
\hline$S U P^{*}$ & $\begin{array}{l}\text { Transcriptional } \\
\text { regulator } \\
\text { SUPERMAN }\end{array}$ & $\begin{array}{l}\text { Transcriptional } \\
\text { regulator considered } \\
\text { as cadastral protein } \\
\text { that acts indirectly to } \\
\text { prevent the B class } \\
\text { homeotic proteins } \\
\text { APETALA3 and } \\
\text { perhaps PISTILLATA } \\
\text { from acting in the } \\
\text { gynoecial whorl. }\end{array}$ & $\begin{array}{l}\text { Meister et al, } \\
2002\end{array}$ & 0 & 0 & 3,4 \\
\hline$T C P 12^{*}$ & $\begin{array}{l}\text { Protein } \\
\text { BRANCHED } 2\end{array}$ & $\begin{array}{l}\text { Transcription factor } \\
\text { that prevents axillary } \\
\text { bud outgrowth. }\end{array}$ & $\begin{array}{l}\text { Bush et al, } \\
\text { 2011; Zhu et al, } \\
2013\end{array}$ & 0 & 0 & 3,45 \\
\hline$M Y B 61 *$ & $\begin{array}{l}\text { Transcription } \\
\text { factor MYB61 }\end{array}$ & $\begin{array}{l}\text { Transcription factor } \\
\text { that coordinates a } \\
\text { small network of } \\
\text { downstream target } \\
\text { genes required for } \\
\text { several aspects of } \\
\text { plant growth and } \\
\text { development. }\end{array}$ & $\begin{array}{l}\text { Asrovski et } \\
\text { al,2009; Liang } \\
\text { et al, } 2005\end{array}$ & 0,96 & 0,43 & 4,16 \\
\hline
\end{tabular}




\begin{tabular}{|l|l|l|l|l|l|l|}
\hline MYB5* & $\begin{array}{l}\text { Transcription } \\
\text { repressor MYB5 }\end{array}$ & $\begin{array}{l}\text { It is expressed in } \\
\text { trichomes, seed coat } \\
\text { and siliques. }\end{array}$ & $\begin{array}{l}\text { Romano et al, } \\
\text { 2012; Yang et } \\
\text { al, 2012; }\end{array}$ & 0,88 & 0,14 & $\mathbf{5 , 3 7}$ \\
\hline
\end{tabular}

1 
Table 3 (on next page)

Genes expressed exclusively in female transcriptomes (F, $1 \mathrm{~F}$ and $2 \mathrm{~F}$ ). 


\begin{tabular}{|c|c|c|c|c|c|c|}
\hline $\begin{array}{l}\text { Gene } \\
\text { homolog }\end{array}$ & $\begin{array}{l}\text { Encoding } \\
\text { protein }\end{array}$ & $\begin{array}{l}\text { RPKM } \\
\text { value (F) } \\
\text { HiSeq2000 } \\
\end{array}$ & $\begin{array}{l}\text { RPKM } \\
\text { value (1F) } \\
\text { NextSeq500 } \\
\end{array}$ & $\begin{array}{l}\text { RPKM } \\
\text { value (2F) } \\
\text { NextSeq500 }\end{array}$ & Function & References \\
\hline PBL9 & $\begin{array}{l}\text { serine/threoni } \\
\text { ne protein } \\
\text { kinase }\end{array}$ & 88.97 & 640.35 & 57.32 & $\begin{array}{l}\text { Exhibits } \\
\text { serine/threonine } \\
\text { activity. }\end{array}$ & $\begin{array}{l}\text { Hirayama and } \\
\text { Oka, 1992; } \\
\text { Ito et al, } 1997\end{array}$ \\
\hline$S U P$ & $\begin{array}{l}\text { Transcription } \\
\text { al regulator } \\
\text { SUPERMAN }\end{array}$ & 7.52 & 123.31 & 56.55 & $\begin{array}{l}\text { Acts indirectly } \\
\text { to prevent AP3 } \\
\text { and perhaps PI } \\
\text { proteins from } \\
\text { acting in the } \\
\text { gynoecial } \\
\text { whorl. }\end{array}$ & $\begin{array}{l}\text { Kazama et al, } \\
2009 \text {; } \\
\text { Bowman et al, } \\
1992\end{array}$ \\
\hline$A C A 7$ & $\begin{array}{l}\text { calcium- } \\
\text { transporting } \\
\text { ATPase } 7, \\
\text { plasma } \\
\text { membrane- } \\
\text { type }\end{array}$ & 22.57 & 0 & 4.92 & $\begin{array}{l}\text { Carbonic } \\
\text { anhydrase that } \\
\text { catalyses the } \\
\text { reaction of } \\
\text { reversible } \\
\text { hydration of } \\
\mathrm{CO}_{2} \text {. }\end{array}$ & $\begin{array}{l}\text { Henry, 1996; } \\
\text { Smith and } \\
\text { Ferry, } 2000\end{array}$ \\
\hline ТCP12 & $\begin{array}{l}\text { Transcription } \\
\text { factor TCP12 }\end{array}$ & 12.6 & 239.69 & 134.51 & $\begin{array}{l}\text { Prevents axillary } \\
\text { bud outgrowth, } \\
\text { delay early } \\
\text { axillary bud } \\
\text { development. }\end{array}$ & $\begin{array}{l}\text { Bush et al, } \\
\text { 2011; Zhu et } \\
\text { al, 2013 }\end{array}$ \\
\hline MYB5 & $\begin{array}{l}\text { Transcription } \\
\text { repressor } \\
\text { MYB5 }\end{array}$ & 19.01 & 122.98 & 75.4 & $\begin{array}{l}\text { Involved in seed } \\
\text { coat formation, } \\
\text { trichome } \\
\text { morphogenesis } \\
\text { and mucilage } \\
\text { secretion. }\end{array}$ & $\begin{array}{l}\text { Romano et al, } \\
2012 \text {; } \\
\text { Yang et al, } \\
2012 \text {; Li et al, } \\
2009 \text {; } \\
\text { Liu et al, } 2014\end{array}$ \\
\hline WIP2 & $\begin{array}{l}\text { Zinc finger } \\
\text { protein WIP2 }\end{array}$ & 7.29 & 131.11 & 114.05 & $\begin{array}{l}\text { Required for } \\
\text { normal } \\
\text { differentiation } \\
\text { of the ovary } \\
\text { transmitting } \\
\text { tract cells. }\end{array}$ & $\begin{array}{l}\text { Crawford and } \\
\text { Yanofsky, } \\
\text { 2008; Marsch } \\
\text { et al, } 2014\end{array}$ \\
\hline MYB61 & $\begin{array}{l}\text { Transcription } \\
\text { repressor } \\
\text { MYB61 }\end{array}$ & 7.59 & 205.63 & 349.61 & $\begin{array}{l}\text { Required for } \\
\text { seed coat } \\
\text { mucilage } \\
\text { deposition. }\end{array}$ & $\begin{array}{l}\text { Asrovski et al, } \\
2009 \text {; } \\
\text { Liang et al, } \\
2005\end{array}$ \\
\hline$L A C 2$ & Laccase-2 & 30.84 & 0 & 3.93 & $\begin{array}{l}\text { LAC2 deficient } \\
\text { lead to early } \\
\text { flowering }\end{array}$ & Tashian 1989 \\
\hline$B E E$ & $\begin{array}{l}\text { Transcription } \\
\text { factor BEE1 }\end{array}$ & 5.29 & 0 & 59.63 & $\begin{array}{l}\text { Positive } \\
\text { regulator of } \\
\text { brassinosteroid } \\
\text { signaling (BR). }\end{array}$ & $\begin{array}{l}\text { Domaglaska et } \\
\text { al, } 2007\end{array}$ \\
\hline
\end{tabular}


2

3

Peer) reviewing PDF | (2019:01:34305:3:0:NEW 27 Jun 2019) 


\section{Table 4 (on next page)}

Genes expressed exclusively in male transcriptomes (M, 1M, 2M). 


\begin{tabular}{|c|c|c|c|c|c|c|}
\hline $\begin{array}{l}\text { Gene } \\
\text { homolog }\end{array}$ & $\begin{array}{l}\text { Encoding } \\
\text { protein }\end{array}$ & $\begin{array}{l}\text { RPKM } \\
\text { value } \\
\text { (M) } \\
\text { HiSeq2000 }\end{array}$ & $\begin{array}{l}\text { RPKM } \\
\text { value } \\
(\mathbf{1 M}) \\
\text { NextSeq500 }\end{array}$ & $\begin{array}{l}\text { RPKM } \\
\text { value } \\
(2 M) \\
\text { Nextseq500 }\end{array}$ & Function & References \\
\hline$p c C 13-62$ & $\begin{array}{l}\text { Desiccation- } \\
\text { related protein }\end{array}$ & 1126.37 & 4335.81 & 5839.66 & $\begin{array}{l}\text { Expressed exclusively } \\
\text { in the stylopodium. }\end{array}$ & $\begin{array}{l}\text { Zha et al, } \\
2013\end{array}$ \\
\hline $\begin{array}{l}\text { CYP450 } \\
86 B 1\end{array}$ & $\begin{array}{l}\text { Cytochrome } \\
\text { P450 }\end{array}$ & 906.19 & 4304.38 & 3499.78 & $\begin{array}{l}\text { Effect the suberin and } \\
\text { cutin biosynthesis. }\end{array}$ & $\begin{array}{l}\text { Duan and } \\
\text { Schuler, } \\
2015 \text {, } \\
\text { Compagnon } \\
\text { et al, } 2019\end{array}$ \\
\hline GDSL2 & $\begin{array}{l}\text { Lipase/Acylh } \\
\text { ydrolase } \\
\text { superfamily } \\
\text { protein }\end{array}$ & 804.54 & 2230.36 & 1603.26 & $\begin{array}{l}\text { Expressed during petal } \\
\text { differentiation. }\end{array}$ & Ji et al, 2017 \\
\hline$O A S$ & $\begin{array}{l}\text { 3-oxoacyl- } \\
\text { [acyl-carrier- } \\
\text { protein] } \\
\text { synthase }\end{array}$ & 737.44 & 326.14 & 303.02 & $\begin{array}{l}\text { Catalyses the } \\
\text { condensation reaction } \\
\text { of fatty acid synthesis. }\end{array}$ & $\begin{array}{l}\text { Dayan and } \\
\text { Duke, 2014; } \\
\text { Hakozaki et } \\
\text { al, } 2008\end{array}$ \\
\hline$P M A D S 2$ & PMADS 2 & 309.49 & 1968.72 & 2038.71 & $\begin{array}{l}\text { Pi (Pistillata) } \\
\text { homologue, } \\
\text { predominantly } \\
\text { expressed in petals and } \\
\text { stamens. }\end{array}$ & $\begin{array}{l}\text { van der Krol, } \\
1993\end{array}$ \\
\hline MYB80 & $\begin{array}{l}\text { Transcription } \\
\text { factor } \\
\text { MYB80 }\end{array}$ & 170.82 & 440.74 & 381.95 & $\begin{array}{l}\text { Play an essential role } \\
\text { during anther } \\
\text { development. }\end{array}$ & $\begin{array}{l}\text { Higginson et } \\
\text { al, 2003; } \\
\text { Phan et al, } \\
2011\end{array}$ \\
\hline MYB35 & $\begin{array}{l}\text { Transcription } \\
\text { factor } \\
\text { MYB35 }\end{array}$ & 144.81 & 426.79 & 398.56 & $\begin{array}{l}\text { Required for anther } \\
\text { development and early } \\
\text { tapetal function during } \\
\text { microspore maturation. }\end{array}$ & $\begin{array}{l}\text { Zhu et al, } \\
2011\end{array}$ \\
\hline TET8 & Tetraspanin 8 & 140.82 & 236.92 & 250.22 & $\begin{array}{l}\text { Expression was } \\
\text { observed during the } \\
\text { pollen development and } \\
\text { in mature pollen. }\end{array}$ & $\begin{array}{l}\text { Reimann et } \\
\text { al, 2017; } \\
\text { Honys and } \\
\text { Twell, 2004; } \\
\text { Pina et al, } \\
2005 \text {; } \\
\text { Boavida et al, } \\
2013\end{array}$ \\
\hline MYB44 & $\begin{array}{l}\text { Transcription } \\
\text { factor } \\
\text { MYB44 }\end{array}$ & 99.18 & 137.58 & 135.46 & $\begin{array}{l}\text { Represses the } \\
\text { expression of protein } \\
\text { phosphatases } 2 \mathrm{C} \text { in } \\
\text { response to abscisic } \\
\text { acid. }\end{array}$ & $\begin{array}{l}\text { Jung et al, } \\
2008\end{array}$ \\
\hline
\end{tabular}




\begin{tabular}{|l|l|l|l|l|l|l|}
\hline NIP & Aquaporin & 49.68 & 51.78 & 25.27 & $\begin{array}{l}\text { Play role in pollen } \\
\text { germination and } \\
\text { pollination }\end{array}$ & $\begin{array}{l}\text { di Giorgio et } \\
\text { al, 2016 }\end{array}$ \\
\hline SYN & Syntaxin & 45.70 & 80.96 & 76.05 & $\begin{array}{l}\text { Syntaxins mediate } \\
\text { membrane fusion. }\end{array}$ & $\begin{array}{l}\text { Sanderfoot et } \\
\text { al, 2001 }\end{array}$ \\
\hline MYB26 & $\begin{array}{l}\text { Transcription } \\
\text { factor } \\
\text { MYB26 }\end{array}$ & 15.57 & 183,91 & 212,97 & $\begin{array}{l}\text { Regulates lignified } \\
\text { secondary cell wall } \\
\text { thickening of the anther } \\
\text { endotechium. }\end{array}$ & $\begin{array}{l}\text { Mitsuda et al, } \\
\text { Yang et al, } \\
2007\end{array}$ \\
\hline
\end{tabular}

